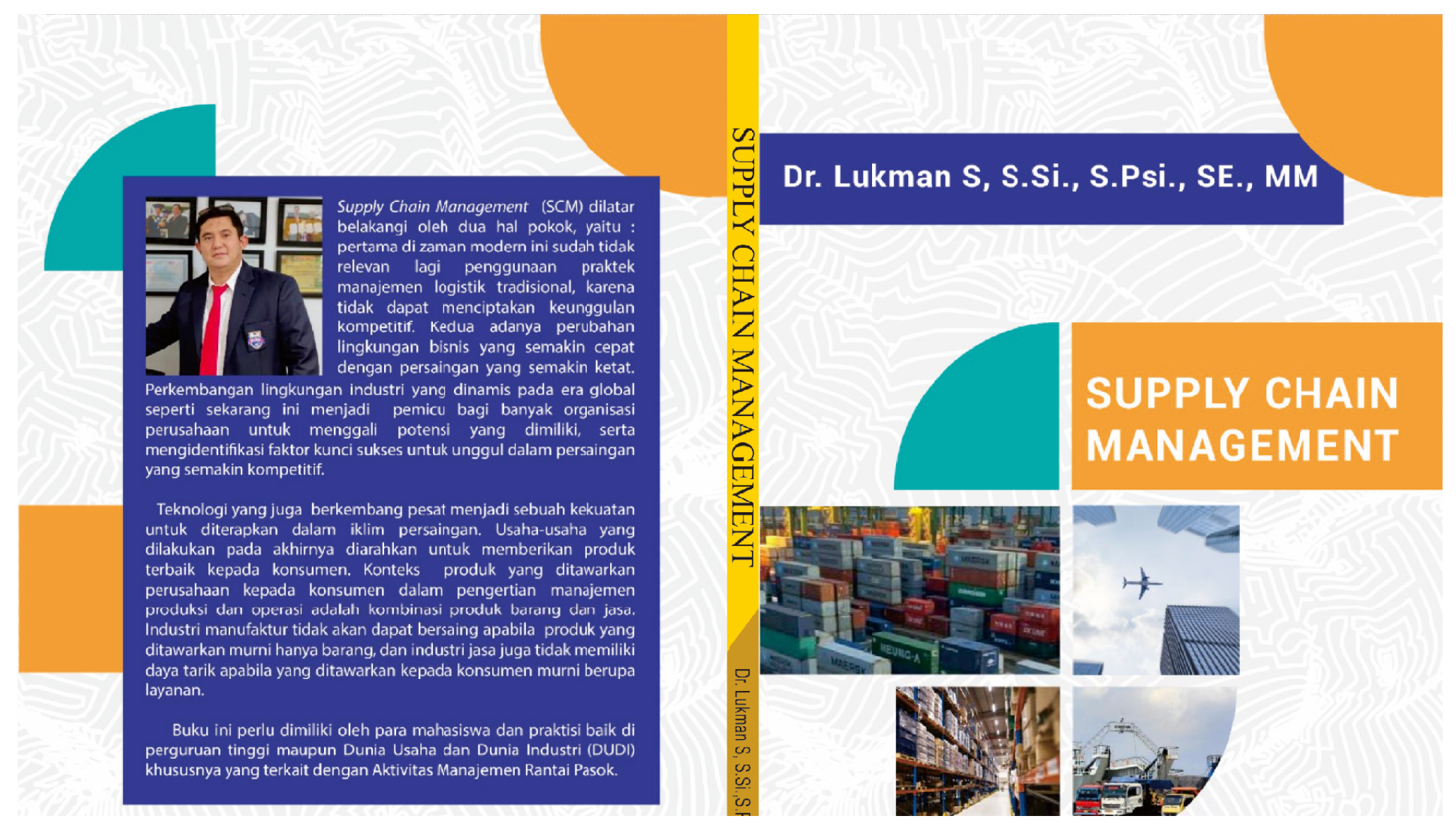




\section{SUPPLY CHAIN MANAGEMENT}

\section{Penulis}

Dr. Lukman S, S.Si, S.Psi.,SE.,MM

Penerbit CV. Cahaya Bintang Cemerlang 


\title{
SUPPLY CHAIN MANAGEMENT
}

Penulis:

Dr. Lukman S, S.Si, S.Psi.,SE.,MM

ISBN 978-623-6032-10-7

Editor :

Prof. Dr. Okto R. Payangan, M.Si.

Penyunting:

Muh. Nur Fajrin

Putri Irmawati

Desain Sampul dan Tata Letak

Muh. Yunus Nabbi

Penerbit:

Percetakan CV. CAHAYA BINTANG CEMERLANG

Redaksi :

Jl. Dr. Wahidin Sudirohusodo BTN Indira Residence Blok E No. 10

Sungguminasa Kab. Gowa

No. HP: 085256649684

Email : muhyunusnabbi@gmail.com

\author{
Distributor Tunggal \\ Percetakan CV. CAHAYA BINTANG CEMERLANG
}

Jl. Dr. Wahidin Sudirohusodo BTN Indira Residence Blok E No. 10

Sungguminasa Kab. Gowa

No. HP: 085256649684/ WA: 085290480054

$\mathrm{http} / / \mathrm{cv}$-cahayabintangcemerlang.co.id

Anggota UMKM Nomor : 04933-0615-20

Anggota IKAPI Nomor : 027/SSL/2020

Cetakan Pertama, Oktober 2021

Hak cipta dilindungi Undang-undang

Dilarang memperbanyak karya tulis ini dalam bentuk dan dengan cara

Apapun tanpa ijin tertulis dari Penerbit. 


\section{KATA PENGANTAR}

Puji syukur kehadirat Tuhan Yang Maha Esa, karena berkat rahmat dan hidayah-Nya penulis dapat menyelesaikan buku yang berjudul “Supply Chain Management". Buku ini ditulis dengan tujuan untuk membantu akademisi dan praktisi dalam Pelaksanaan Operasional Manajemen Rantai Pasok.

Supply Chain Management (SCM) atau strategi pemasok dilatar belakangi oleh dua hal pokok, yaitu : pertama di zaman modern ini sudah tidak relevan lagi penggunaan praktek manajemen logistik tradisional, karena tidak dapat menciptakan keunggulan kompetitif. Kedua adanya perubahan lingkungan bisnis yang semakin cepat dengan persaingan yang semakin ketat. Perkembangan lingkungan industri yang dinamis pada era global seperti sekarang ini menjadi pemicu bagi banyak organisasi perusahaan untuk menggali potensi yang dimiliki, serta mengidentifikasi faktor kunci sukses untuk unggul dalam persaingan yang semakin kompetitif. Teknologi yang juga berkembang pesat menjadi sebuah kekuatan untuk diterapkan dalam iklim persaingan. Usaha-usaha yang dilakukan pada akhirnya diarahkan untuk memberikan produk terbaik kepada konsumen. Konteks produk yang ditawarkan perusahaan kepada konsumen dalam pengertian manajemen produksi dan operasi adalah kombinasi produk barang dan jasa. Industri manufaktur tidak akan dapat bersaing apabila produk yang ditawarkan murni hanya barang, dan industri jasa juga tidak memiliki daya tarik apabila yang ditawarkan kepada konsumen murni berupa layanan. Keberhasilan perusahaan dalam memberikan produk terbaik kepada konsumen meliputi kombinasi di 
antara keduanya, yaitu barang dan jasa dalam porsi masing-masing yang ideal menurut perusahaan. Menyajikan produk dalam arti luas tersebut merupakan tantangan sekaligus peluang bagi sistem produksi operasi yang harus dijalankan perusahaan. Pada dasarnya konsumen mengharapkan dapat memperoleh produk yang memiliki manfaat pada tingkat harga yang dapat diterima. Untuk mewujudkan keinginan konsumen tersebut maka setiap perusahaan berusaha secara optimal untuk menggunakan seluruh asset dan kemampuan yang dimiliki untuk memberikan value terhadap harapan konsumen.

Besar harapan kami, buku ini dapat memberikan pengetahuan Suplly Chain Management. Penulis juga menyadari buku ini masih belum sempurna. Kritik, saran, dan koreksi dari pembaca sangat membantu penulis dalam memperbaiki tulisan dalam edisi berikutnya. Terima Kasih.

Makassar, Oktober 2021

Penulis,

Lukman S. 


\section{DAFTAR ISI}

HALAMAN SAMPUL............................................ i

HALAMAN REDAKSI …......................................... ii

KATA PENGANTAR ............................................... iii

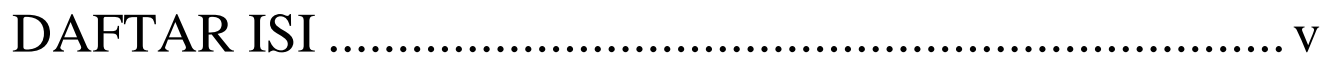

PART I LANDASAN TEORI SCM ….......................... 1

A. Kajian Teori Supply Chain Management (scm) ....... 1

B. Defenisi dan Ruang Lingkuyp (SCM) ..................... 5

C. Ruang Lingkup SCM......................................... 7

D. Supply Chain Network ...................................... 9

E. Strategi SCM ........................................................ 11

F. Komponen Supply Chain Management................... 15

G. Tujuan Utama Supply Chain Management ............. 16

H. Proses Supply Chain Management .......................... 17

PART 2 SUKSES SCM - AKSES SCM.......................... 22

A. Definisi Sukses SCM dan Akses SCM................... 22

B. Perbandingan SCM dan DCM ............................... 23

C. Kolaborasi SCM dan DCM ................................... 25

PART 3 LATAR BELAKANG SCM ............................ 27

A. Sejarah SCM................................................... 27

B. Munculnya SCM dilatar belakangi oleh..................27

C. Perbandingan SCM dan Manajemen Logistik.......... 28

PART 4 PRINSIP DAN STRATEGI SCM..................... 30
A. Konsep SCM........................................................ 30

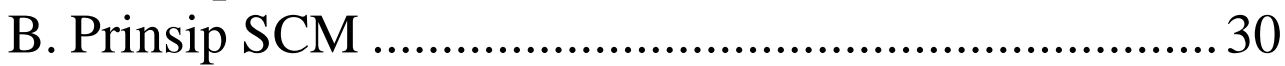
C. Aktivitas SCM ...................................................... 31
D. Strategi SCM ...................................................... 32

PART 5 MANFAAT DAN KINERJA SCM ................... 34

A. Manfaat SCM ........................................................ 34

B. Mengukur Kinerja SCM .................................... 34 


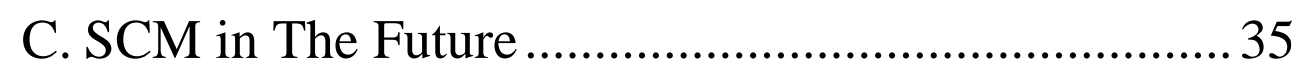

D. Tren International SCM................................................ 36

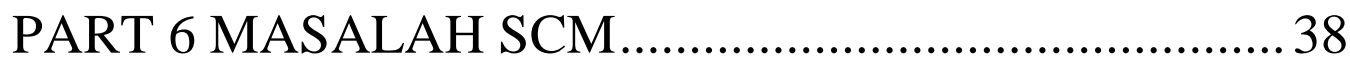

A. Faktor Ketidakpastian SCM ..................................... 38

B. Bullwhip Effect (BE)................................................ 39

C. Masalah SCM ........................................................... 39

PART 7 SOLUSI DAN MASALAH SCM ........................41

A. Solusi Masalah SCM ............................................... 41

PART 8 PERANAN MANAJEMEN PEMASOK, PRODUKSI DAN LOGISTIK DALAM SCM... 43

A. Peranan Manajemen Pemasok Dalam SCM .............. 43

B. Peranan Manajemen Produksi dalam SCM ............... 45

C. Peranan Manajemen Logistik dalam SCM ................ 46

PART 9 PENETAPAN MANAJEMEN PENGADAAN

DALAM SCM .................................................. 48

A. Pengertian Pengadaan ................................................. 48

B. Peranan Pengadaan dalam SCM................................ 48

C. Aktivitas Pengadaan dalam SCM ............................... 48

D. Kontrak .................................................................. 49

E. Keputusan Pengadaan (Decision to procure)............. 49

F. Lead time Pengadaan................................................... 49

G. Apresiasi Produk Dalam Negeri (Appreciation of

Domestic Product) ………………………………...... 49

H. Kontrak Kemitraan (Strategic Alliances) .................. 49

I. Total Cost of Ownership (TCO)...............................50

J. Original Equipment Manufacturer (OEM) ................50 50

K. Procurement One ............................................................. 51

L. Pengadaan Sentralisasi vs Desentralisasi ...................51

M. Produsen vs Trader .................................................52

N. Pemasok Internasional vs Pemasok Nasional ..........52 
O. Brand Name vs Generic

PART 10 PERANAN TRANSPORTASI BARANG \& MANAJEMEN PERGUDANGAN DALAM SCM

A. Peranan Transportasi barang ............................... 53

B. Peranan Manajemen Pergudangan dalam SCM .......59

PART 11 PERANAN MANAJEMEN DISTRIBUSI DALAM SCM ..............................................6 62

A. Peranan Manajemen distribusi dalam SCM ............ 62

PART 12 PERANAN MANAJEMEN PELANGGAN DAN INVENTORI ................................................69

A. Peranan manajemen pelanggan dalam SCM ............ 69

B. Peranan Manajemen Inventori dalam SCM............. 71

PART 13 PERANAN MAJEMEN MATERIAL \& ASET DALAM SCM ............................................... 75

A. Peranan Manajemen Material dalam SCM.............. 75

PART 14 PERANAN MANAJEMEN PERAMALAN KEBUTUHAN, INFOMASI, KUALITAS DANLINGKUMNGAN DALAM SCM ...........81 81

A. Peranan Manajemen Peramalan Kebutuhan Dalam SCM ................................................................ 81

B. Peranan Manajemen Informasi Dalam SCM........... 82

C. Peranan Manajemen Kualitas dalam SCM.............. 83

D. Peranan Manajemen Lingkungan dalam SCM........ 84

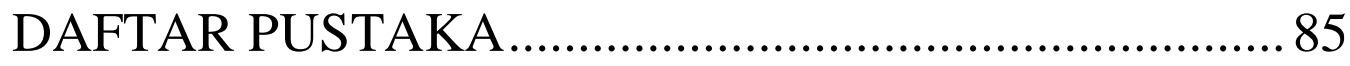

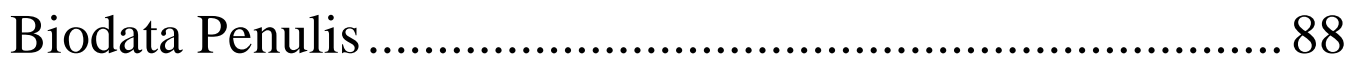




\section{PART I}

\section{LANDASAN TEORI SCM}

\section{A. Kajian Teori Suply Chain Management (SCM)}

Menurut J. A. O'Brien (2006), SCM adalah sistem antar perusahaan lintas fungsi, yang menggunakan teknologi informasi untuk membantu mendukung, serta mengelola berbagai hubungan antara beberapa proses bisnis utama perusahaan dan dengan pemasok, pelanggan, dan para mitra bisnis. Manajemen rantai pasokan atau Supply Chain Management merupakan manajemen aliran barang dan jasa dan mencakup semua proses yang mengubah bahan mentah menjadi produk jadi. Sebenarnya proses scm melibatkan perampingan aktif dari kegiatan sisi penawaran bisnis dalam memaksimalkan nilai pelanggan dan mendapatkan keunggulan kompetitif dalam persaingan pasar.

Menurut James A \&Mona J. Fitzsimmons, pengertian Supply Chain Management adalah sebuah sistem pendekatan total untuk dapat mengantarkan produk ke konsumen akhir dengan menggunakan teknologi informasi di dalam mengkoordinasikan seluruh elemen supply chain dari mulai pemasok ke pengecer. Menurut 
Chase, Aquilano, dan Jacob, pengertian SCM adalah sebuah sistem untuk dapat menerapkan pendekatan secara total didalam mengelola seluruh aliran informasi, bahan, serta juga jasa dari bahan baku dengan melalui pabrik serta gudang hingga ke konsumen akhir.

Menurut Russell dan Taylor, pengertian SCM adalah sebuah proses mengelola arus informasi, produk serta pelayanan di seluruh jaringan baik pelanggan, perusahaan hingga pemasok.

Menurut Stevenson, definisi SCM adalah suatu koordinasi strategis dari rantai pasokan dengan tujuan untuk dapat mengintegrasikan manajemen penawaran serta permintaan.

Menurut Robert, Gail, dan Lund pengertian SCM adalah seluruh kegiatan atau aktivitas yang terlibat didalam menghantarkan produk dari bahan baku dengan melalui pelanggan termasuk sumber bahan baku serta suku cadang, manufaktur dan juga perakitan, pergudangan serta pelacakan inventaris, pesanan yang masuk dan juga manajemen pesanan, distribusi di seluruh saluran, pengiriman ke pelanggan, dan juga sistem informasi yang diperlukan untuk memantau seluruh kegiatan. 
Pengertian manajemen rantai pasokan atau Supply chain Management adalah suatu rangkaian pendekatan yang digunakan untuk mengintegrasikan pemasok, produsen, gudang serta juga toko dengan secara efektif supaya persediaan barang itu dapat diproduksi serta juga didistribusi pada jumlah yang tepat, ke lokasi yang tepat, dan pada waktu yang tepat sehingga biaya keseluruhan sistem itu dapat diminimalisir selagi berusaha dapat memuaskan kebutuhan serta layanan.

Menurut Heizer dan Rander, Supply Chain Management adalah suatu kegiatan pengelolaan berbagai kegiatan atau aktivitas dalam rangka mendapatkan bahan mentah menjadi barang setengah jadi serta juga barang jadi, setelah itu mengirimkan produk tersebut ke konsumen dengan melalui sistem distribusi

Levi, et.al (2000) mendefinisikan Supply Chain Management (Manajemen Rantai Pasokan) sebagai suatu pendekatan yang digunakan untuk mencapai pengintegrasian yang efisien dari supplier, manufacturer, distributor, retailer, dan customer. Artinya barang diproduksi dalam jumlah yang tepat, pada saat yang tepat, dan pada tempat yang tepat dengan tujuan mencapai suatu 
biaya dari sistem secara keseluruhan yang minimum dan juga mencapai service level yang diinginkan.

Pires, et.al. (2001) mengartikan Supply Chain Management (Manajemen Rantai Pasokan) sebagai sebuah jaringan supplier, manufaktur, perakitan, distribusi, dan fasilitas logistik yang membentuk fungsi pembelian dari material, transformasi material menjadi barang setengah jadi maupun produk jadi, dan proses distribusi dari produk-produk tersebut ke konsumen.

Chow et.al. (2006) mengartikan Supply Chain Management (Manajemen Rantai Pasokan) sebagai pendekatan yang holistik dan strategis dalam hal permintaan, operasional, pembelian, dan manajemen proses logistik.

Manajemen Rantai Suplai (Supply chain management) adalah sebuah 'proses payung' di mana produk diciptakan dan disampaikan kepada konsumen dari sudut struktural. Sebuah supply chain (rantai suplai) merujuk kepada jaringan yang rumit dari hubungan yang mempertahankan organisasi dengan rekan bisnisnya untuk mendapatkan sumber produksi dalam menyampaikan kepada konsumen.

SCM merupakan integrasi dan organisasi pengelolaan rantai suplai dan kegiatan melalui hubungan organisasi 
koperasi, proses bisnis yang efektif, dan tingkat tinggi berbagi informasi untuk menciptakan sistem nilai berkinerja tinggi yang memberikan organisasi anggota keunggulan kompetitif yang berkelanjutan

SCM merupakan upaya pemasok untuk mengembangkan dan menerapkan rantai pasokan yang seefisien dan seekonomis mungkin. Rantai pasokan mencakup segala hal, mulai dari produksi dan pengembangan produk hingga sistem informasi yang diperlukan guna mengarahkan usaha dalam perusahaan.

\section{B. Definisi dan Ruang Lingkup SCM}

Defenisi Supply Chain Management yang diterbitkan baik oleh para pakar maupun institusi SCM di seluruh dunia dilatar belakangi oleh pengetahuan, ruang lingkup dan kepentingan masing-masing. Beberapa defenisi SCM yang dikutip oleh penulis, masih relevan dengan praktik bisnis dan teknologi dalam kegiatan aliran barang. Penulis mendefinisikan SCM sesuai cara pandang komprehesif berdasarkan konsep academic (pengetahuan), business (bisnis), dan Goverment (regulator) yang disingkat ABG.

\section{Council of Supply Chain Management Professionals,}

Supply Chain Management encompasses the planing and management of all activities involved in sourcing 
and procurement, conversion, and all logistic management activities, importantly, it also includes coordination and collaboration with channel partners, which can be suppliers, intermediaries, third party service providers, and customers. In essence, supply chain management intergrates supply and demand management within and across companies.

\section{Institute of Supply Management (ISM),}

Supply Chain Management as the identification, acquisition, access, positioning and management of resource and related capabilities the organization needs or potentially needs in the attainment of strategic objectives.

\section{Willem Siahaya,}

Supply Chain Management is the integration of competent business source of flow of goods encompasses the planning and management of procurement and logistic activities and related information from the point of origin to the point of consumption, includes coordination and collaboration with channel partners (supplier, manufacturer, warehouse, transporter, distributor, retailer and 
customer) for the purpose of conforming to customers requirements.

Supply Chain (Rantai Pasok) adalah suatu sistem organisasi dalam kegiatan penyaluran barang (flow of goods) kepada pelanggan. Supply Chain merupakan jaringan dari berbagai organisasi yang saling berhubungan dan mempunyai tujuan yang sama dalam menyelenggarakan penyaluran barang dengan baik.

Supply Chain Management merupakan pengintegrasian sumber-sumber bisnis yang kompeten baik dalam maupun di luar perusahaan untuk mendapatkan sistem suplai yang kompetitif dan berfokus kepada sinkronisasi aliran produk dan informasi untuk menciptakan nilai pelanggan (customer value) yang tinggi. Sumber-sumber bisnis yang diintegrasikan meliputi Pemasok (Supplier), Pabrikan, Gudang, Pengangkut, Distributor, Retailer dan Konsumen yang bekerja secara efisien sehingga produk yang dihasilkan dan didistribusikan memenuhi tepat jumlah, kualitas, waktu dan lokasi

\section{Ruang Lingkup SCM}

Supply Chain Management (SCM) melaksanakan kegiatan aliran barang yang meliputi perencanaan, pengadaan, produksi, penyimpanan, transportasi, dan 
distribusi, mulai dari titik awal bahan baku (hulu) sampai ke titik pemakaian (hilir).

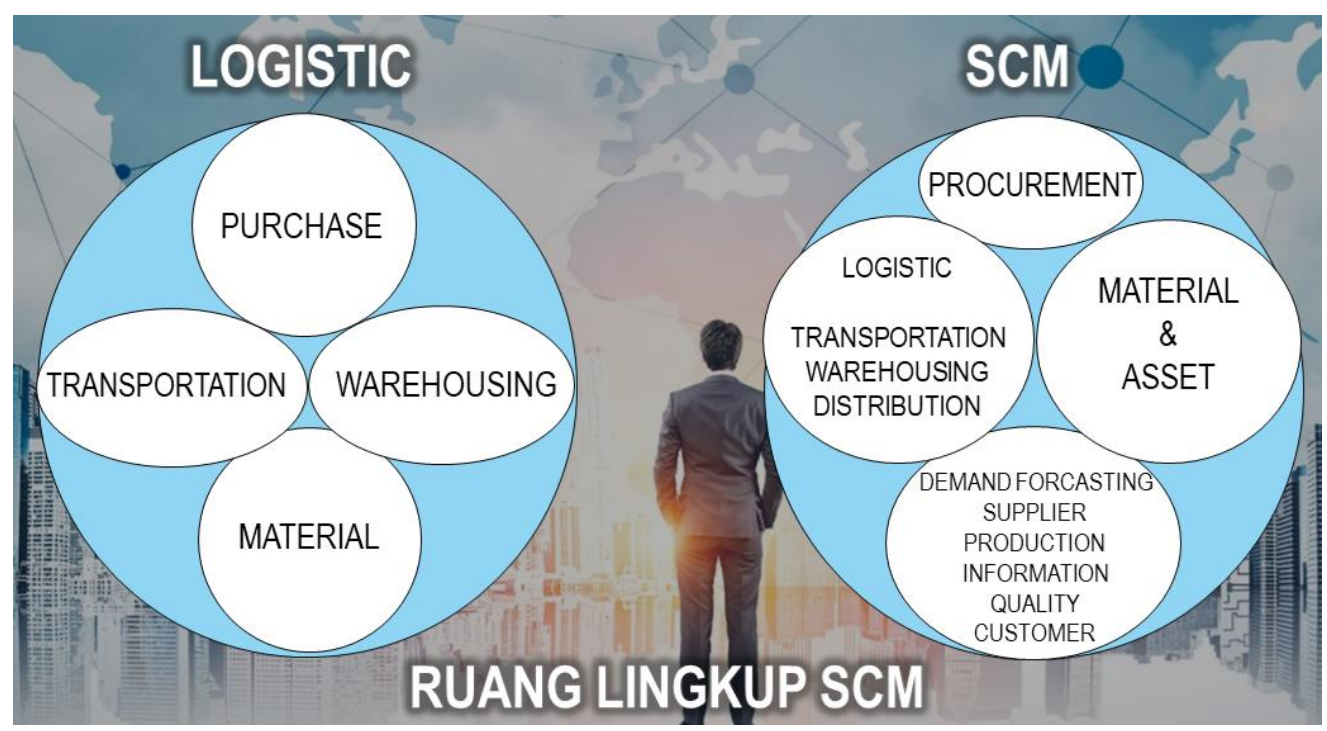

SCM Link terdiri dari 7 (tujuh) mata rantai yang merupakan pelangi SCM yaitu Supplier, Manufacturer, Warehouse, Transportation, Distributor, Retailer, dan Customer. Elemen pendukung SCM terdiri dari 9 (sembilan) elemen manajemen yang sangat berperan dalam keberhasilan kegiatan aliran barang yaitu elemen yang meliputi procurement, logistik (transportasi, pergudangan, distribusi), inventory (persedian), Demand Forecasting, Supplier, Production, Information, Quality dan Customer. 


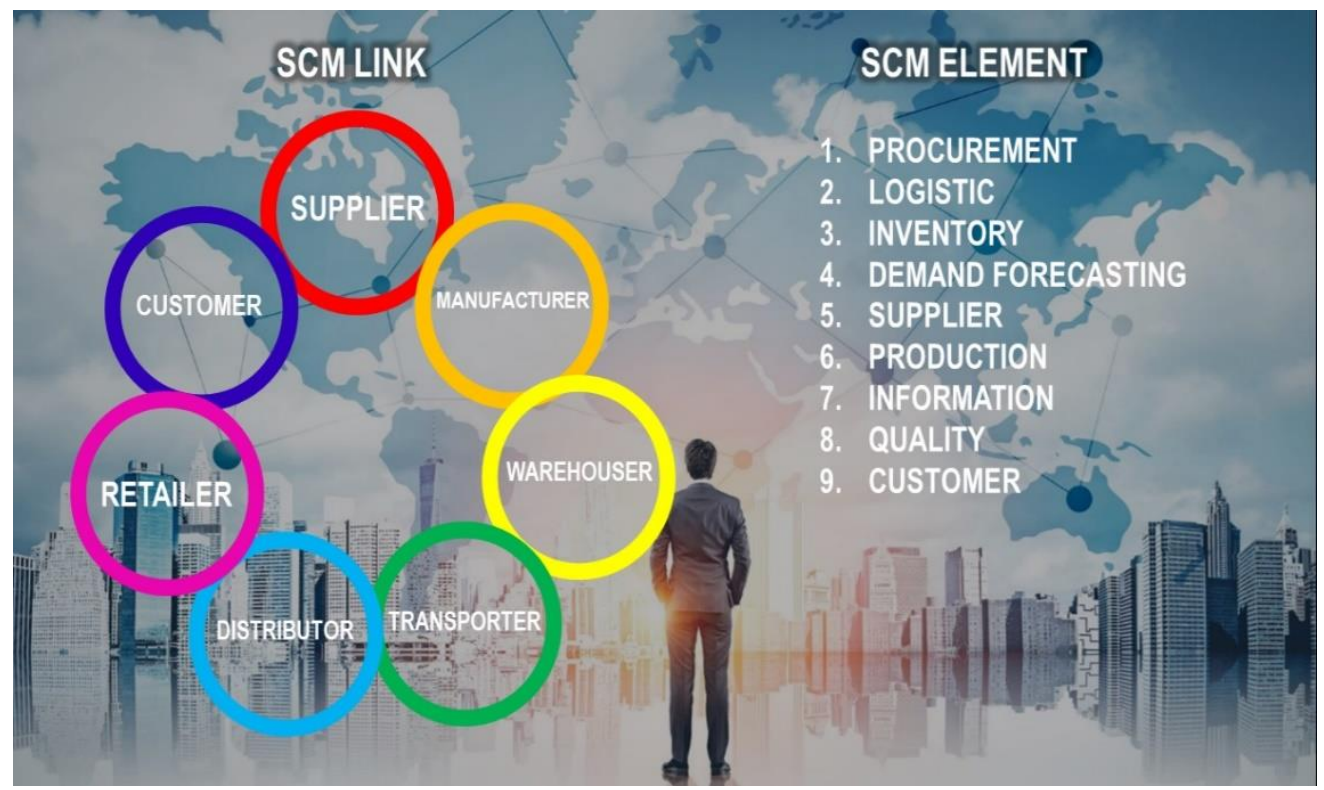

\section{Supply Chain Network}

Merancang Supply Chain Network (jaringan rantai pasok) merupakan keputusan yang sangat penting, karena merupakan keputusan yang sangat penting, karena merupakan strategi jangka panjang dan memerlukan biaya besar apabila terjadi perubahan yang memerlukan perbaikan dan penyesuaian. Kegiatan SCN menyangkut

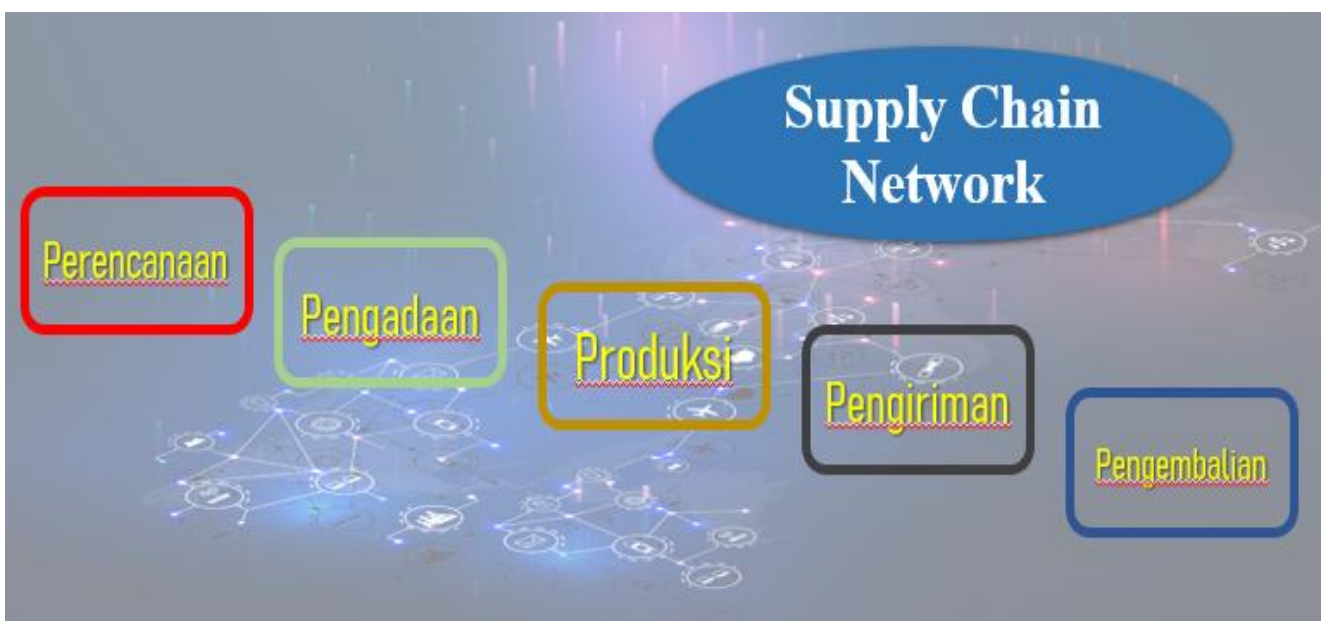


Hal dasar yang perlu diperhatkan untuk membangun SCN yang optimal:

\section{Perencanaan}

Perencanaan adalah proses penyeimbangan antara permintaan dan pasokan untuk menentukan tindakan terbaik dalam memenuhi kebutuhan.

2. Pengadaan

Penentuan sumber pengadaan dan pemilihan pemasok yang terbaik serta pelaksanaan kontrak untuk menjaga kualitas, komitmen, transportasi, waktu penyerahaan barang serta sistem pembayaran.

3. Produksi

Mentransformasi bahan baku (raw material) menjadi produk jadi (finished product) sesuai kebutuhan pelanggan.

4. Pengiriman

Pengaturan pengiriman pesanan pelanggan, jaringan pergudangan dan distribusi, pemilihan distributor dan sistem ekspedisi.

5. Pengembalian

Mengidentifikasi kondisi produk dan menangani proses pengembalian barang dari konsumen karena kesalahan pengiriman dan carat atau rusak. 


\section{E. Srategi SCM}

\section{Strategi Supply Chain Management}

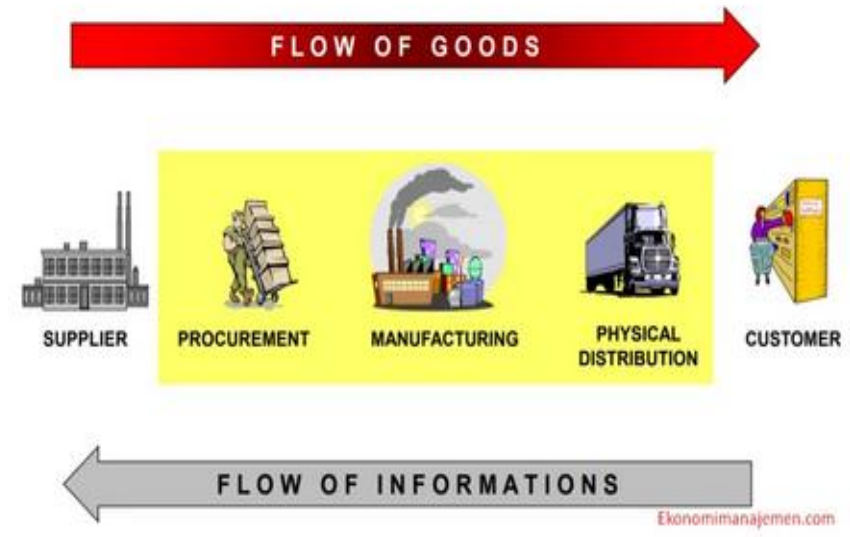

Jay Heizer dan Barry Render sudah mengemukakan sejumlah strategi guna menghadapi tantangan dan permasalahan SCM, di dalam bukunya yang berjudul "Manajemen Operasi", adapun strategi dalam SCM, yakni

1. Bernegosiasi dengan Banyak Pemasok

Strategi pertama adalah bernegosiasi dengan banyak pemasok. Kita dapat mencari banyak pemasok dan memilih diantara mereka yang memiliki penawaran paling menarik bagi perusahaan. Umumnya perusahaan menjatuhkan pilihan bagi pemasok yang memberikan penawaran rendah, tetapi sebaiknya jangan hanya memilih satu pemasok, pilihlah beberapa pemasok agar jika suatu hari terjadi masalah kepada salah satu 
pemasok, rantai pasokan perusahaan tidak terputus dan tetap dapat melanjutkan kegiatan perusahaan.

2. Mengembangkan hubungan kemitraan

Strategi kedua adalah mengembangkan hubungan kemitraan jangka panjang dengan sedikit pemasok untuk memuaskan hubungan pelanggan. Para pemasok yang telah lama menjalin hubungan dengan perusahaan mungkin dapat lebih memahami tujuan dari perusahaan dan biasanya lebih berkomitmen untuk berpartisipasi dalam sistem just in time, dimana perusahaan tidak lagi mempunyai gudang untuk persediaan mereka karena pemasok akan mengirim persediaan tepat saat perusahaan membutuhkannya. Hal ini tidak mudah dilakukan, karena itu perusahaan biasanya hanya mau menerapkan sistem ini pada para pemasok yang telah mereka percayai. Jika dibandingkan, perusahaan yang menggunakan pemasok yang sedikit dapat menekan biaya menjadi lebih rendah daripada perusahaan yang mempunyai banyak pemasok, karena pasti akumulasi biaya kirim dari pemasok yang berbeda-beda akan lebih besar. Intinya, kita boleh saja memilih beberapa pemasok tetapi jangan terlalu banyak memilih pemasok 
karena hanya akan menimbulkan biaya yang lebih besar.

\section{Integrasi Vertikal}

Strategi ketiga adalah integrasi vertikal, artinya perusahaan berusaha mengembangkan kemampuan untuk memproduksi barang atau jasa yang sebelumnya diperoleh dari pemasok. Ada dua macam integrasi, yaitu integrasi maju dan integrasi mundur. Integrasi mundur menyarankan perusahaan untuk membeli pemasoknya, sehingga mereka dapat membuat barang sesuai keinginan mereka. Integrasi maju menyarankan produsen komponen untuk membuat produk jadi. Tetapi integrasi mundur bisa menjadi berbahaya bagi perusahaan yang sedang mengalami perubahan teknologi, karena jika salah menginvestasikan uang yang mereka miliki maka mereka akan kesusahan dalam menghadapi gelombang teknologi yang berikutnya.

\section{Jaringan Keiretsu}

Strategi keempat adalah jaringan keiretsu, yaitu kombinasi dari sedikit pemasok dengan integrasi vertikal. Dengan strategi ini pemasok akan menjadi bagian dari perusahaan dan yang pasti akan terjadi 
hubungan kerja sama jangka panjang antar keduanya. Diharapakan dari strategi ini, mutu dari produk yang dihasilkan akan tetap terjaga.

\section{Virtual Company}

Strategi terakhir atau kelima adalah mengembangkan perusahaan maya (virtual company) yang menggunakan para pemasok sesuai kebutuhan. Strategi ini mengandalkan berbagai jenis hubungan pemasok untuk menyediakan jasa atas permintaan yang diinginkan. Perusahaan maya memiliki batasan organisasi yang berubah dan bergerak yang membuat mereka mampu untuk memenuhi permintaan pasar yang berubah-ubah. Para pemasok dapat menyediakan berbagai jasa, seperti pembayaran upah, perekrutan karyawan, dan lainnya. Jika perusahaan menggabungkan keunggulan dari perusahaan maya, manajemen perusahaan yang bagus, biaya yang rendah, maka perusahaan akan mendapatkan efisiensi. Penerapan Supply Chain Management pada perusahaan yang memiliki komitmen, visi, misi dan pilihan strategi yang baik akan menghasilkan keuntungan yang lebih besar daripada perusahaan lain. 


\section{F. Komponen Supply Chain Management}

Pemahaman tentang SCM mengacu pada definisi dari pendapat ahli. Olehnya itu perlu pemahaman terkait komponan utama dalam SCM. Adapun komponen utama dalam SCM :

\section{Upstream Supply Chain}

Upstream supply chain manajemen mengurus hubungan antara perusahaan dengan vendor atau pihak lain dalam hal transfer barang. Jadi barang-barang yang diproduksi oleh perusahaan tidak langsung sampai ke tangan konsumen tapi disalurkan ke perusahaan penyalur lainnya.

Misalnya sebuah perusahaan yang memproduksi smartphone. Produk smartphone ini tidak serta-merta sampai ke tangan konsumen langsung, tapi pihak manufacturer akan mengirimkan produknya ke suplier

2. Downstream Supply Chain

Downstream supply chain mangement adalah manajemen yang mengurusi transfer barang dari perusahaan langsung ke konsumen. Jadi kalau upstream supply chain harus lewat supplier dulu, kalau downstream langsung bisa dibeli oleh konsumen. Contoh management ini yaitu mebel atau gallery art. 
Jadi mereka membuat produk langsung sesuai keinginan konsumen.

\section{Internal Supply Chain}

Internal supply chain management berkaitan dengan aktifitas pemasukan barang. Dalam hal ini yang kerap diperhatikan yaitu manajemen produksi, pabrikasi, dan juga kontrol ketersediaan bahan baku

\section{G. Tujuan Utama Supply Chain Management}

Setelah memahami pengertian, strategi, dan komponen SCM, maka selanjutnya harus memahami tentang tujuan SCM, Menurut pendapat Stevenson, tujuan supply chain management adalah menyelaraskan antara permintaan dan penawaran secara efektif dan efisien. Beberapa masalah utama yang ada di dalam rantai pasokan berhubungan dengan:

1. Penentuan tingkat outsourcing yang tepat

2. Manajemen pengadaan barang

3. Manajemen pemasok

4. Mengelola hubungan dengan pelanggan

5. Identifikasi masalah dan merespon masalah tersebut

6. Manajemen risiko 
Menurut pendapat I Nyoman Pujawan, tujuan strategis dari rantai pasokan adalah untuk memenangkan persaingan pasar atau setidaknya bertahan. Karena itu, menurut I Nyoman Pujawan, untuk menjadi pemenang dalam persaingan pasar maka rantai pasokan harus bisa menyediakan produk yang :

1. Murah

2. Berkualitas

3. Tepat waktu

4. Bervariasi

\section{H. Proses Supply Chain Management}

Dalam manajemen rantai pasokan (SCM), prosesnya dibagi menjadi tiga macam tanggungjawab, diantaranya:

\section{Arus Material}

Arus material ini melibatkan pergerakan produk mentah dari suplier ke konsumen dan juga dari konsumen yang dikembalikan atau retur produk, layanan, daur ulang dan pembuangan.

\section{Arus Informasi}

Arus informasi ini berisi tentang prediksi permintaan, informasi perpindahan barang, dan juga peng-update-an status barang apakah sudah terkirim atau belum. 


\section{Arus Finansial}

Arus finansial berisi pembayaran, alur perkreditan, penjadwalan pembayaran hingga persetujuan kepemilikan. Alur informasi yang akurat dan bergerak dengan mudah di antara mata rantai, serta pergerakan barang yang efektif dan efisien menjadi faktor kunci keberhasilan dalam manajemen rantai pasokan. Menurut pendapat Indrajit dan Djokopranoto, ada beberapa pelaku yang ada pada rantai pasokan, diantaranya:

1. Supplier

2. Manufacturer

3. Distributor / wholesaler

4. Retail outlets

5. Customers

Biasanya, SCM berupaya mengendalikan atau menghubungkan produksi, pengiriman, dan distribusi suatu produk secara terpusat. Dengan mengelola rantai pasokan, perusahaan dapat memotong biaya berlebih dan mengirimkan produk ke tangan konsumen lebih cepat.

Hal ini dilakukan dengan cara menjaga kontrol yang lebih ketat atas inventaris internal, produksi 
internal, distribusi, penjualan, dan inventaris vendor perusahaan. SCM didasarkan pada gagasan bahwa hampir setiap produk yang datang ke pasar dihasilkan dari upaya berbagai organisasi yang membentuk rantai pasokan.

Meskipun rantai pasokan telah ada sejak dulu, sebagian besar perusahaan baru-baru ini memperhatikannya sebagai nilai tambah bagi operasi mereka. Dalam SCM, manajer rantai pasokan mengoordinasikan logistik semua aspek rantai pasokan yang terdiri dari 5 bagian diantaranya:

1. Rencana atau strategi

2. Sumber (bahan baku atau layanan)

3. Manufaktur (fokus pada produktivitas dan efisiensi)

4. Pengiriman dan logistik

5. Sistem pengembalian (untuk produk yang cacat atau tidak diinginkan)

Manajer rantai pasokan (SCM) mencoba meminimalkan kekurangan dan menekan biaya. Pekerjaan ini bukan hanya tentang logistik dan pembelian persediaan. Dikutip dari laman Salary.com, manajer rantai pasokan, "membuat rekomendasi untuk meningkatkan produktivitas, kualitas, dan efisiensi 
operasi."Peningkatan dalam produktivitas dan efisiensi langsung menuju garis bawah perusahaan dan memiliki dampak nyata dan abadi. Manajemen rantai pasokan yang baik membuat perusahaan keluar dari berita utama dan jauh dari penarikan dan tuntutan hukum yang mahal.

\section{Contoh Supply Chain Management}

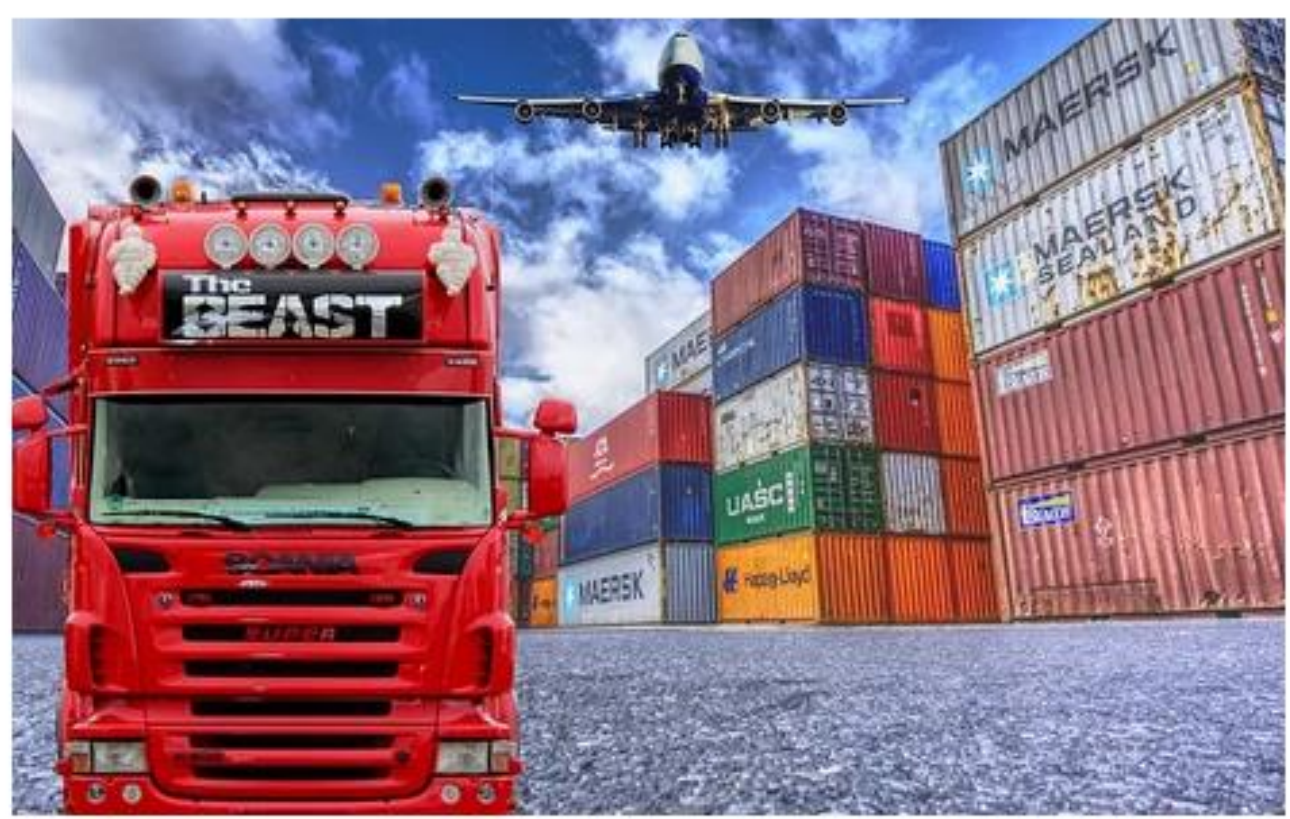

Dikutip dari laman investopedia.com, pemahaman pentingnya SCM untuk bisnisnya, Walgreens Boots Alliance Inc. berupaya keras untuk mentransformasikan rantai pasokannya pada 2016. Perusahaan ini mengoperasikan salah satu rantai farmasi terbesar di Amerika Serikat dan perlu mengelola dan merevisi rantai pasokannya secara efisien 
sehingga tetap di depan tren yang terus berubah dan terus menambah nilai pada intinya.

Pada tanggal 5 Juli 2016, Walgreens telah berinvestasi di bagian teknologi dari rantai pasokannya. Ini menerapkan SCM berwawasan ke depan yang mensintesis data yang relevan dan menggunakan analitik untuk meramalkan perilaku pembelian pelanggan, dan kemudian bekerja dengan cara mendukung rantai pasokan untuk memenuhi permintaan yang diharapkan.

Sebagai contoh, perusahaan dapat mengantisipasi pola flu, yang memungkinkannya untuk secara akurat memperkirakan persediaan yang dibutuhkan untuk obat flu yang dijual bebas, menciptakan rantai pasokan yang efisien dengan sedikit limbah. Dengan menggunakan SCM ini, perusahaan dapat mengurangi kelebihan persediaan dan semua biaya terkait persediaan, seperti biaya pergudangan dan transportasi. 


\section{PART 2 \\ SUKSES SCM - AKSES SCM}

\section{A. Definisi Sukses SCM dan Akses SCM}

Sukses (success) SCM sudah terbukti dan teruji, mampu memberikan keberhasilan secara menyeluruh kepada perusahaan, berupa produk berkualitas dan peningkatan pendapatan, daya saing, kecepatan, ketepatan proses dan layanan. Pelaksanaan kegiatan SCM melalui tindakan efisiensi, mampu mengurangi lead time pengadaan, biaya, inventori dan kesalahan peramalan kebutuhan.

Akses (Access) DCM merupakan jalan masuk untuk lebih fokus pada penanganan kebutuhan pelanggan, melalui tindakan efektivitas yang berawal dan bertolak dari kepentingan dan kebutuhan pelanggan. Konsumen semakin menuntut keberagaman karakter kebutuhan sehingga kebutuhan konsumen semakin kompleks dan dinamis. Kondisi ini menyebabkan perusahaan harus lebih fokus dan fleksibel terhadap kebutuhan konsumen. 


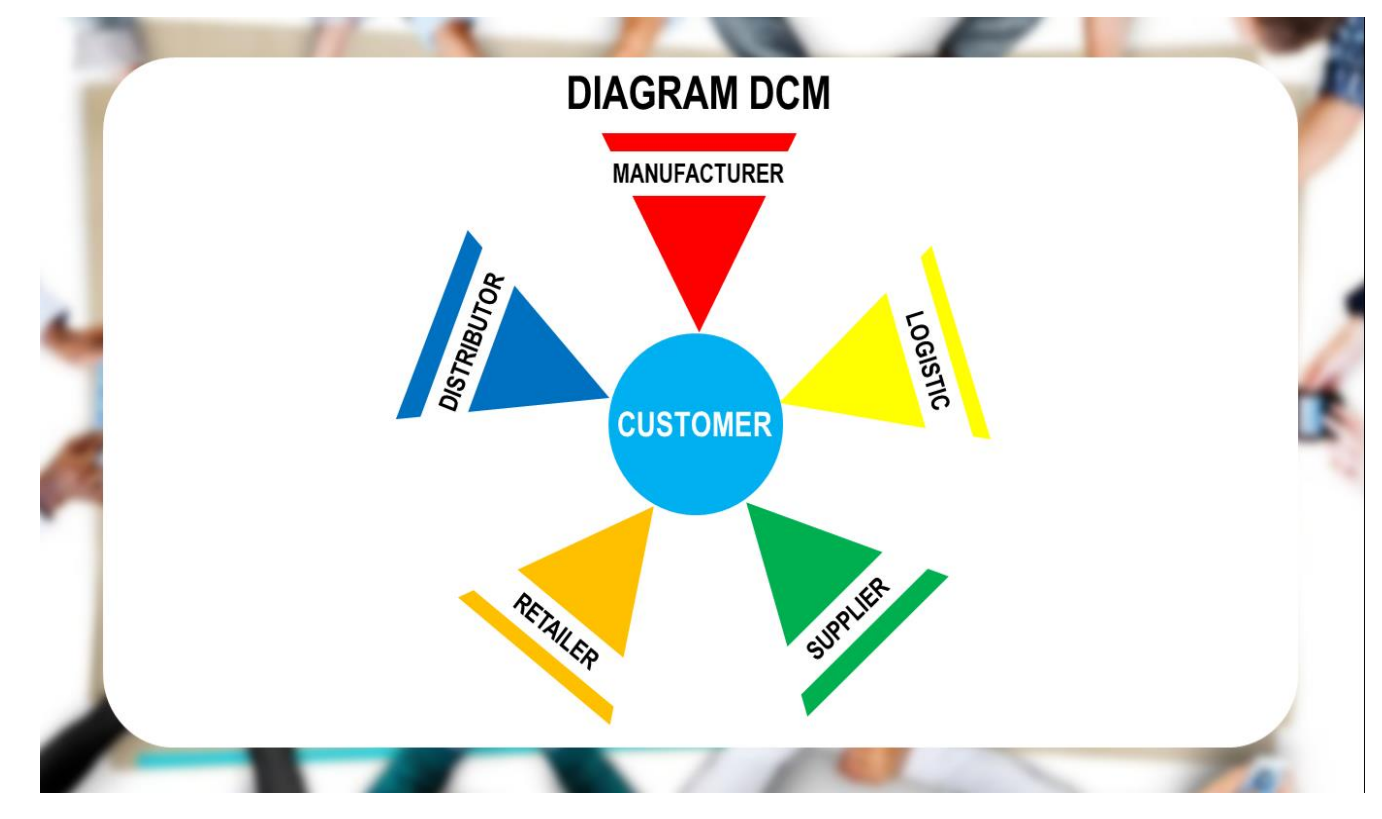

Konsentrasi pelaksanaan kegiatan DCM:

1. Produk yang dihasilkan popular dan up to date.

2. Produk berkualitas.

3. Produk bervariatif.

4. Persediaan produk terjamin.

5. Pengiriman cepat, tepat waktu dan aman.

6. Harga kompetitif berdasarkan kualitas.

7. Pelayanan prima.

Responsif terhadap komplain pelanggan.

\section{B. Perbandingan SCM dan DCM}

\section{Orientasi}


a. SCM melaksanakan tindakan efisiensi (daya guna) meliputi pengurangan biaya,inventori, lead time dan proses suplai.

b. DCM melaksanakan tindakan efektivitas (hasil guna) berorientasi pada pasar yang bertujuan meningkatkakn pelayanan pelanggan (customer service), pangsa pasar (market share), penjualan (sales), produk baru (new product), layanan purna jual (after sales service) dan kepuasan pelanggan (customer satisfication).

\section{Fokus}

a. SCM fokus pada engineering practices atas aliran produk dari produsen ke distributor dan arus informasi antar perusahaan serta mengurangibiaya operasional.

b. DCM Fokus pada kebutuhan dan layanan pelanggan.

\section{Push dan Pull System}

a. SCM Merupakan push system yang berusaha untuk menentukan kebutuhan pelanggan melalui peramalan yang akurat menuju efisiensi biaya dan kecepatan proses.

b. DCM merupakan pull system yang bertolak dari kebutuhan pelanggan menuju efektivitas pelayanan. 


\section{Prinsip}

a. Prinsip SCM, pengelolaan proses pengadaan produksi, logistik dan distribusi, baik di dalam maupun di luar perusahaan.

b. Prinsip DCM, pengelolaan komunikasi tentang pengetahuan dan informasi tentang konsumen dan pasar ke perusahaan mitra.

\section{Strategi}

a. SCM merupakan kolaborasi antara pemasok, produsen, logistik, distribusi dan pelanggan.

b. DCM merupakan kombinasi antara manajemen pemasaran, pelanggan dan kebutuhan pelanggan.

\section{Kolaborasi SCM dan DCM}

1. DCM merupakan manajemen yang berkembang dari nilai kebutuhan pelanggan.

2. DCM yang berorientasi pada efektivitas kebutuhan pelanggan merupakan pelengkap bagi SCM yang berorientasi pasa efesiensi proses produksi dan aliran barang.

3. SCM dan DCM menyeimbangkan penerapan sistem push dan pull.

4. Bersama meningkatkan profitabilitas perusahaan mitra. 
5. Bersama menciptakan hubungan seimbang antara semua perusahaan anggota jejaring. 


\section{PART 3}

\section{LATAR BELAKANG SCM}

\section{A. Sejarah SCM}

Supply chain management (SCM) berawal dari kegiatan logistik militer yang sangat berperan dalam menentukan kemenangan perang. Teknik logistik kemudian dipakai dalam kegiatan pengiriman barang dan terjadi kerjasama antara perusahaan pengiriman barang dan terjadi kerjasama antara perusahaan pengiriman barang dengan gudang.

Pada saat muncul teknologi informasi, ilmu logistik berkembang lebih pesat dan lebih efesien melalui komunikasi dan kolaborasi sehingga dapat menekan biaya produksi, meningkatkan kualitas dan mengurangi kesalahan manusia.

\section{B. Munculnya SCM dilatar belakangi oleh :}

1. Kegiatan manajemen logistik dianggap bersifat tradisional dan adversarial, dimana pada era modern sudah tidak relevan, karena tidak menciptakan keunggulan kompetitif. 
2. Perkembangan lingkungan bisnis yang dinamis dan kemajuan teknologi yang makin cepat menimbulkan persaingan yang semakin ketat.

3. Adanya keharusan membuat produk berkualitas dengan harga yang kompetitif dan pengiriman produk cepat dan tepat waktu.

4. Adanya tren kemitraan (pathnership) Kerjasama antar perusahaan yang bersinergi dan mempunyai tujuan (goal) yang sama, saling percaya dan merupakan ikatan perjanjian jangka panjang.

5. Adanya tren outsourcing (pengalihan kegiatan) Mengalihkan sebagian kegiatan perusahaan yang bukan merupakan bisnis utama kepada pihak ketiga yang kompeten, supaya perusahaan lebih efisien dan fokus kepada bisnis utama (core business).

6. Persaingan tidak lagi antar individu perusahaan tapi antar jejaring bisnis.

7. Pemenuhan kebutuhan pelanggan yang dinamis.

\section{Perbandingan SCM dan Manajemen Logistik}

SCM merupakan pengembangan dari manajemen logistik yang mempunyai dasar prinsip yang sama, namun 
keduanya mempunyai karakteristik yang berbeda dalam melaksanakan kegiatan aliran barang.

1. Persamaan

- Melaksanakan kegiatan aliran barang

- Melakukan kegiatan pemesanan, penyimpanan, pengangkutan dan pengiriman barang.

- Melakukan peningkatan efisiensi pada seluruh rangkaian kegiatan aliran barang (flow of goods).

2. Perbedaan

- Manajemen logistik

Mengutamakan pengelolaan aliran barang dalam perusahaan. Berorientasi pada perencanaan dan kerangka kerja serta informasi internal perusahaan.

- Supply Chain Management

Mengutamakan pengelolaan aliran barang antar perusahaan. Berorientasi pada perencanaan dan kerangka kerja serta informasi yang terintegrasi antar perusahaan, sejak dari hulu (supplier) sampai hilir (customer) 


\section{PART 4}

\section{PRINSIP DAN STRATEGI SCM}

\section{A. Konsep SCM}

1. Mengintegrasikan dan mensinkronkan pemasok, manufaktur dan distributor

2. Mengurangi jumlah pemasok

3. Kemitraan (Partnership/strategic alliances)

4. Kegiatan SCM mendekat kesumber dan pelaksanaan pengadaan langsung ke produsen, tanpa melalui perantara yag akan menambah biaya. Supplier dalam SCM berarti produsen, bukan perantara

\section{B. Prinsip SCM}

1. Prinsip Integrasi, semua elemen yang terlibat dalam rangkaian SCM berada dalam satu kesatuan yang kompak dan bersama menyadari adanya saling ketergantungan.

2. Prinsip Jejaring, semua elemen berada dalam hubungan kerja yang selaras.

3. Prinsip Ujung Ke Ujung, proses operaional mencakup elemen pemasok yang paling hulu sampai ke konsumen yang paling hilir. 
4. Prinsip Saling Tergantung, setiap elemen dalam SCM menyadari bahwa untuk mencapai tujuan bersama dan meningkatkan daya saing, diperlukan kerjasama yang saling menguntungkan.

5. Prinsip Komunikasi, data yang akurat memberikan informasi tepat untuk memperlancar aliran barang.

6. Prinsip Kemitraan, pemasok, manufaktur, distributor dan pelanggan bekerjasama, saling membagi dan mengkomunikasikan informasi, mempunyai tujuan yang sama, saling percaya dan mengutamakan kualitas dan waktu.

7. Prinsip Dukungan, mendapat dukungan penuh dari manajemen dan fungsi operasional perusahaan dalam proses perencanaan, koordinasi, pelaksanaan dan pengendalian.

\section{Aktivitas SCM}

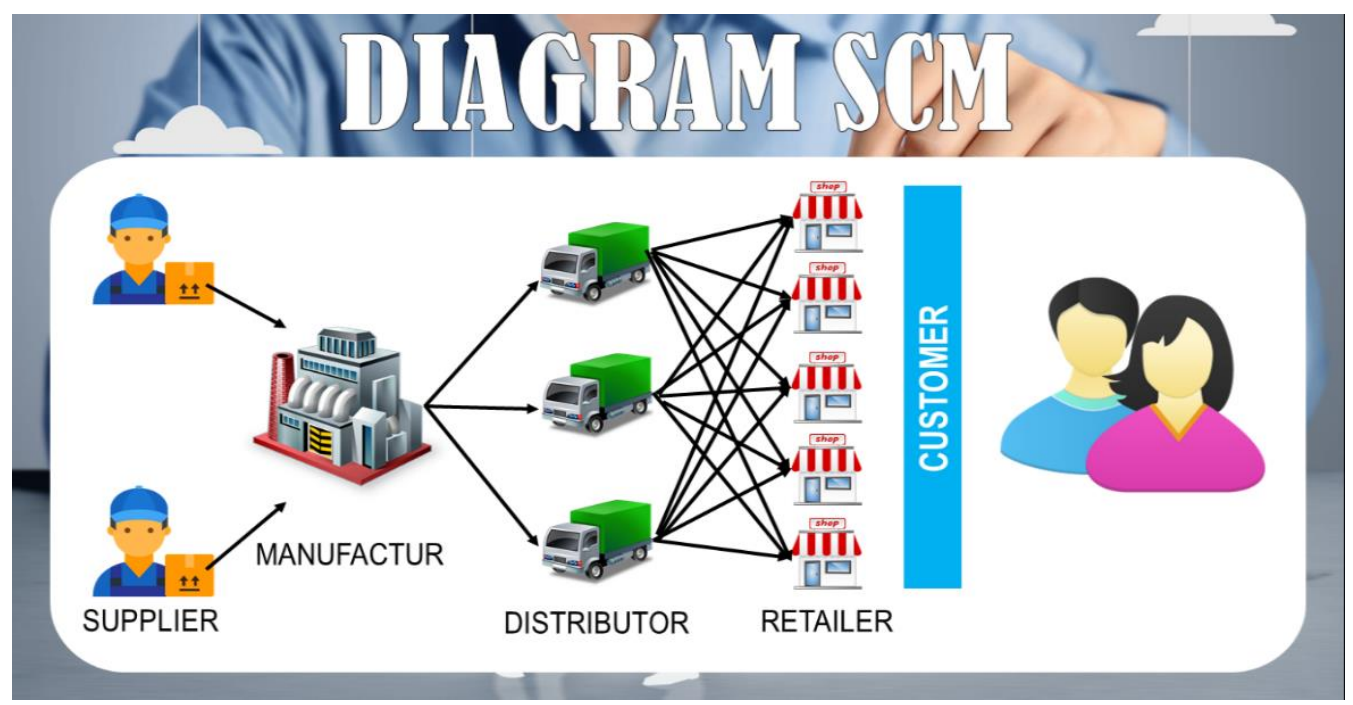




\section{Strategi SCM}

Strategi Supplai Chain Management adalah rangkaian kegiatan dan aksi strategis pada jalur aliran barang yang menciptakan rekonsiliasi antara apa yang dibutuhkan pelanggan akhir dengan kemampuan sumber daya yang ada pada jaringan supply chain.

\section{Tujuan Strategi SCM}

- Cost Reduction, meminimalkan biaya di semua sektor.

- Service Improvement, meningkatkan tingkat layanan (service lead).

- Responsif dalam menghadapi perubahan lingkungan bisnis yang sangat cepat.

- Memperolesh kepercayaan dari semua unsur terkait terutama pelanggan.

- Mengembangkan prinsip kemitraan.

\section{Model Strategi SCM}

- Extended Enterprise, kebijakan menggunakan sedikit pemasok untuk kepentingan jangka panjang.

- Vertical Integration, perusahaan memproduksi bahan baku sendiri.

- Backward Integration, perusahaan membeli Supplier.

- Forward Integration, membuat barang jadi sendiri. 
- Virtual Organization, berorientasi kepasa proyek.

\section{Fokus Strategi SCM}

Pelanggan : Kebutuhan dan kepuasan pelanggan

Pemasok : Kemitraan

Pesaing : Persaingan secara sehat dan bersinergi

Perusahaan : Analisis SWOT dan penerapan strategi

\section{Faktor Strategi SCM}

- Kemampuan Bersaing (Competitive Advantage), yaitu kemampuan untuk unggul dalam persaingan.

- Fleksibilitas Permintaan (Demand Flexibility), Yaitu kemampuan untuk memenuhi perubahan kebutuhan konsumen terhadap jumlah, spesifikasi dan delivery.

- Kemampuan Proses (Process capability), yaitu kemampuan untuk menjalankan aktivitas produksi sesuai standar industri secara efektif.

- Kematangan Proses (Process Maturity), yaitu kinerja manufaktur untuk memenuhi permintaan.

- Strategi Risiko (Risk Strategic), yaitu antisipasi terhadap risiko yang timbul. 


\section{PART 5}

\section{MANFAAT DAN KINERJA SCM}

\section{A. Manfaat SCM}

Adapun manfaat SCM

1. Meminimalkan inventori

2. Mengurangi biaya

3. Mengurangi lead time

4. Meningkatkan pendapatan

5. Ketepatan waktu penyerahan

6. Menjamin kelancaran aliran barang

7. Menjamin kualitas

8. Menghindari kehabisan persediaan (stock-out)

9. Meningkatkan akurasi peramalan kebutuhan

10. Kepuasan pelanggan

11. Mengurangi jumlah pemasok (supplier)

12. Mengembangkan kemitraan (partnership)

13. Peningkatan kompetensi SDM

14. Perusahaan semakin berkembang

15. Meningkatkan daya saing

\section{B. Mengukur Kinerja SCM}

Mengukur kinerja aktivitas SCM melalui tolok ukur: 
1. Biaya

2. Waktu

3. Kapasitas

4. Kapabilitas

5. Produktivitas

6. Utilisasi

7. Outcome

\section{SCM in The Future}

1. Expanding the Supply Chain, Ekspansi sumber dan kehandalan serta ketersediaan bahan baku sampai ke layer kedua dan ketiga.

2. The greening of Supply Chain, dalam pelaksanaan setiap proses dan aktivitas supply chain, harus menerapkan prinsip berwawasan lingkungan.

3. Increasing Supply Chain Responsiveness, upaya meningkatkan peranan dan nilai tambah serta tanggung jawab SCM.

4. Reducing Supply Chain Costs, melakukan efesiensi di sektor SCM untuk menurunkan biaya operasional.

5. Reducing Procurement Costs, melakukan efisiensi di sektor pengadaan atas harga dan kualitas barang. 
6. Outsourcing SC Function, mengalihkan sebagian kegiatan yang bukan merupakan fungsi utama SCM kepada pihak ketiga yang kompeten.

7. Managing inventory along the Supply Chain, pengendalian inventori untuk mendapaykan inventori yang optimal.

8. Meningkatkan kompetensi tenaga kerja SCM berbasis sertifikasi kompetensi bertaraf internasional.

\section{Tren International SCM}

1. Fokus kepada bisnis utama SCM

2. Jaminan proses produksi dan mutu produk

3. Memproduksi produk yang dibutuhkan

4. Fokus kepada pelayanan dan kebutuhan pelanggan

5. Optimalisasi inventori

6. Layanan fleksibel dan cepat

7. Peningkatan daya saing

8. Optimalisasi biaya SCM

9. Peningkatan fungsi koordinasi

10. Peningkatan layanan informasi

11. Hubungan kemitraan dengan suplier

12. Outsourcing beberapa fungsi non-core SCM

13. Dukungan top management

14. Otomatisasi peralatan handling dan gudang 
15. Peningkatan kompetensi tenaga kerja SCM

16. Penerapan etika bisnis

17. Berwawasan lingkungan

18. Penerapan corporate social responsibility (CSR)

19. Pencegahan praktik korupsi

20. Bencmarking terhadap best practice SCM 


\section{PART 6}

\section{MASALAH SCM}

\section{A. Faktor Ketidakpastian SCM}

Hal yang menyebabkan Ketidakpastian SCM

1. Kesalahan peramalan kebutuhan

2. Perubahan jumlah kebutuhan oleh konsumen

3. Pembatalan kontrak

4. Keterlambatan jadwal produksi

5. Kegagalan mesin produksi

6. Kualitas bahan baku dan produk dibawah standar

7. Keterlambatan penerimaan bahan baku

8. Kesalahan dan keterlambatan informasi

9. Kegagalan transportasi

10. Pengukuran kinerja tidak akurat

11. Customer Service tidak dilaksanakan dengan baik

12. Status data pengiriman tidak akurat

13. Sistem informasi tidak efisien

14. Diskriminasi terhadap konsumen

15. Koordinasi tidak dilaksanakan dengan baik

16. Terjadi kendala komunikasi antar perusahaan

17. Rancangan operasional tidak terintegrasi 


\section{B. Bullwhip Effect (BE)}

Bullwhip Effect (BE) adalah suatu keadaan yang terjadi dalam supply chain, dimana permintaan dari konsumen mengalami perubahan yang menyebabkan distorsi permintaan dari setiap tahapan supply chain .

Dampak Bullwhip Effect

1. Stock Pengaman (safety stock) naik

2. Kualitas pelayanan menurun

3. Alokasi sumber daya tidak efisien

4. Biaya transportasi naik

5. Rencana kerja berubah

Mengatasi Bullwhip Effect

1. Mengurangi ketidakpastian, dengan cara berbagi (sharing) informasi dan data peramalan.

2. Mengurangi variabilitas, menghilangkan promosi dan berlakukan harga tetap.

3. Mengurangi lead time, dengan cara menerapkan EDI dan praktik cross-docking (muat dan bongkar langsung tanpa melalui gudang).

4. Kerja strategis, melalui pengaturan persediaan dan berbagi data.

\section{Masalah SCM}

Masalah yang timbul dalam praktik kegiatan SCM: 


\section{Varitas Produk (Variety of Products)}

Strategi perusahaan terfokus kepada konsumen (customer oriented), sehingga produk disesuaikan dengan keinginan individu konsumen. Banyaknya jenis produk membuat produsen sulit memenuhi keinginan konsumen.

2. Umur Product (Product Life Cycle)

Umur produk makim menurun membuat perusahaan sulit mengatur strategi pasokan barang, karena perusahaan membutuhkan waktu khusus.

3. Kebutuhan Pelanggan (Customer Demand)

Konsumen menuntut pemenuhan permintaan secara cepat, meskipun permintaan sangat mendadak dan bukan merupakan produk standar.

4. Fragmentasi Pemilik (Fragmentation of Ownership)

SCM melibatkan banyak pihak dengan kepentingan masing-masing, sehingga membuat kegiatan SCM semakin rumit.

5. Globalisasi (Globalization)

Globalisasi membuat SCM semakin kompleks karena pihak yang terlibat mencakup berbagai negara dan bangsa. 


\section{PART 7}

\section{SOLUSI MASALAH SCM}

\section{A. Solusi Masalah SCM}

1. Melakukan kegiatan outsourcing kegiatan SCM. Mengalihkan sebagian kegiatan yang bukan merupakan bisnis utama kepada pihak ketiga yang kompeten, supaya perusahaan dapat lebih fokus ke bisnis utama (core business) dan lebih efesien.

2. Melaksanakan kemitraan (partnership), perjanjian jangka panjang, mempunyai tujuan yang sama, saling percaya dan saling berbagi resiko.

3. Meminimalkan jumlah supplier, untuk memudahkan kontrol dan menghindari keberagaman.

4. Meningkatkan relationship, hubungan baik di tingkat internal maupun eksternal perusahaan.

5. Mengoptimalkan persediaan bahan baku dan produk jadi melalui pengendalian persediaan.

6. Melakukan proses produksi berdasarkan order, hanya melakukan proses produksi bila telah menerima ordae (Purchase Order) 
7. Memperpendek birokrasi SCM, meniadakan rantai birokrasi yang tidak perlu menambah biaya serta waktu proses.

8. Menerima pesanan langsung dari konsumen, melayani konsumen secara langsung, tanpa melibatkan distributor dan retailer. 


\section{PART 8}

\section{PERANAN MANAJEMEN PEMASOK, PRODUKSI, DAN LOGISTIK DALAM SCM}

\section{A. Peranan Manajemen Pemasok Dalam SCM}

\section{Peranan Pemasok dalam SCM}

Peranan pemasok sangatlah penting bagi kelancaran tugas dan pengembangan supply chain. Pemasok memberikan kontribusi yang sangat besar bagi keberhasilan penyaluran barang sejak dari tempat bahan baku samapi proses produksi.

\section{Analisis Pemasok (Vendor Analysis)}

a. Analisis Penawaran Kompetitif

b. Analisis Teknis

c. Analisis Operasi

d. Analisis Harga

e. Analisis Profit

f. Analisis Biaya

g. Analisis Biaya Terendah (Lowest Price)

\section{Seleksi Pemasok (Vendor Selection)}

Faktor pertimbangan seleksi vendor (pemasok) :

a. Produk dan teknologi produksi

- Mutu produk 
- Teknologi proses produksi

b. Distribusi dan teknologi informasi

- Desain produk baru

- Keterlibatan pemasok dalam kegiatan suplai

- Membangun sistem informasi

- Perbandingan dengan perusahaan sukses

c. Cost (TCO)

Syarat pembayaran, diskon, biaya pemesanan, biaya pemeliharaan dan biaya logistik.

d. Reliabilitas

- Reliabilitas karakter perusahaan

- Reliabilitas lead time pengadaan

- Kegiatan R\&D

e. Sistem dan waktu pengadaan

- Proses pengadaan mudah, cepat dan efektif serta taat kepada peraturan yang berlaku.

- Lead time pengadaan singkat.

\section{Evaluasi Pemasok (Vendor Evaluation)}

Evaluasi pemasok untuk menentukan apakah dapat memenuhi kebutuhan sesuai persyaratan. 


\section{Hubungan Relasi Pemasok (Vendor Relationship)}

Hubungan kerja yang baik antara pengguna (pemberi

kerja) dan pemasok akan memperoleh hasil kerja baik sesuai dengan rencana kerja.

\section{Persyaratan Umum Menjadi Pemasok}

a. Memnuhi ketentuan peraturan perundangan untuk menjalankan usaha sebagai pemasok.

b. Memiliki keahlian, pengalaman, kemampuan teknis dan manajerial bidang pemasokan.

c. Tidak dalam pengawasan pengadilan, tidak pailit dan direksi tidak dalam menjalani sanksi pidana.

d. Membayar kewajiban pajak kepada negara

e. Memiliki SDM, modal, peralatan dan fasilitas sesuai yang diperlukan.

f. Tidak termasuk dalam daftar hitam (Black List)

\section{B. Peranan Manajemen Produksi dalam SCM}

Produksi adalah kegiatan untuk menambah kegunaan suatu barang atau menghasilkan barang atau menghasil barang baru, sehingga lebih bermanfaat dalam memenuhi kebutuhan.

1.Perencanaan produksi 
2. Proses Produksi

3. Production Scheduling

4. Decoupling Point (DP)

5. Biaya Produksi

\section{Peranan Manajemen Logistik dalam SCM}

Manajemen Logistik adalah bagian dari supply chain management yang meencanakan, melaksanakan dan mengendalikan kegiatan pengangkutan, penyimpanan dan distribusi barang serta layanan jasa dan informasi terkait secara efisien dan efektif untuk memenuhi kebutuhan pelanggan. (Willem Siahaya, 2008)

\section{Strategi Logistik}

Meningkatkan responsif terhadap pelanggan, kecepatan dan ketepatan waktu, keamanan dan keselamatan produk dan nilai layanan. Menurunkan biaya transportasi dan menghilangkan pungutan tidak resmi atau penyuapan.

\section{Peranan Logistik dalam SCM}

Logistik sangat berperan dalam menentukan harga barang (produk). Biaya transportasi merupakan bagian terbesar dari biaya logistik. 


\section{Kehandalan Logistik}

Mengoptimalkan kinerja kegiatan logistik untuk meningkatkan daya saing.

\section{Third Party Logistics (TPL)}

TPL Merupakan praktik supply chain dimana sebagian fungsi logistik perusahaan dialihkan kepada pihak ketiga yang kompeten supaya perusahaan dapat meningkatkan daya saing dan mengurangi biaya operasional serta fokus kepada bisnis utama.

\section{Mengukur Keberhasilan Logistik}
a. Ketersediaan / Availability
b. Kemampuan / Capability
c. Mutu / Quality
d. Biaya / Cost
e. Profit Center 


\section{PART 9}

\section{PENERAPAN MANAJEMEN PENGADAAN DALAM \\ SCM}

\section{A. Pengertian Pengadaan}

Pengadaan merupakan profit center, karena terlibat langsung dalam produksi dan kegiatan operasi yang menentukan biaya produksi dan hasil kerja pengadaan berakibat langsung terhadap kinerja serta menentukan keuntungan perusahaan.

\section{B. Peranan Pengadaan dalam SCM}

Manajemen pengadaan berperan sebagai proses penentuan secara sistematik terhadap, apa (spesifikasi, kualitas), kapan (jadwal,delivery time), bagaimana (sumber, sistem) dan beberapa (kuantitas).

\section{Aktivitas Pengadaan dalam SCM}

1. Rencana Kerja Pengadaan

2. Strategi Pengadaan

3. Sumber Pengadaan (Procurement Source)

4. Metode Pemilihan Pemasok

5. Proses Tender 


\section{Kontrak}

Kontrak adalah perikatan perjanjian antara pengguna (Pemberi Kerja) dengan peyedia (pelaksana) yang berisikan hak dan kewajiban dalam pelaksanaan pengadaan barang dan jasa.

\section{E. Keputusan Pengadaan (Decision to procure)}

Keputusan melaksanakan pengadaan berdasarkan:

1. Strategi Operasional (Operational Strategies)

2. Strategi Keuanga (Financial Strategies)

3. Strategi Pemasaran (Marketing Strategies)

4. Strategi Persediaan (inventory strategies)

\section{F. Lead time Pengadaan}

Adalah keseluruhan waktu proses pengadaan barang, mulai sejak barang diminta sampai dengan barang tiba di gudang/lokasi pemakai dan siap dipakai.

\section{G. Apresiasi Produk Dalam Negeri (Appreciation of}

\section{Domestic Product)}

Produk dalam negeri adalah penggerak ekonomi bangsa untuk kesejahteraan masyarakat.

\section{H. Kontrak Kemitraan (Strategic Alliances)}

Kontrak kemitraan adalah kontrak pengadaan barang dan jasa yang berdasarkan konsep kerjasama jangka panjang, dimana para pihak memberikan kontribusi sumber 
dana dan daya serta fasilitas yang dimiliki untuk mencapai sasaran strategis yang disepakati bersama.

\section{Total Cost of Ownership (TCO)}

TCO merupakan prinsip untuk mengetahui dan mengukur semua biaya yang ditimbulkan dalam rangkaian kegiatan rantai pasok guna mendapatkan biaya optimal dan wajar. Setiap perusahaan yang terkait dalam jaringan rantai pasok akan mencapai tujuan dan memperoleh keuntungan (best value) melalui TCO yang optimal.

\section{J. Original Equipment Manufacturer (OEM)}

Pengertian awal OEM (original equipment manufacturer) adalah produsen yang memproduksi komponen atau parts yang disuplai kepada produsen lain yang memproduksi peralatan jadi (finished product) untuk dijual kepada pelanggan.

Pengertian OEM mengalami pergeseran yaitu semua produsen baik yang memproduksi peralatan/equipment maupun yang suplai komponen/parts yang terlibat dalam pembuatan peralatan jadi yang bermerek(branded) tertentu melalui proses pabrikasi. 


\section{K. Procurement One}

Procurement one adalah cara pandang dan pelaksanaan kegiatan pengadaan barang dan jasa berdasarkan kesatuan terintegrasi secara konsekuen meliputi oneregulation (satu peraturan/tata cara), ane interpretation (satu interpretasi/penafsiran) dan one implementation (satu implementasi/pelaksanaan).

\section{Pengadaan Sentralisasi vs Desentralisasi}

1. Alasan diadakan pelaksanaan pengadaan sentralisasi

- Barang dimaksud dipergunakan oleh sebagian besar unit operasi

- Memerlukan pengawasan terhadap kebijakan pengadaan dan pelaksanaan produksi

2. Keuntungan sentralisai

- Komunikasi dengan pemasok cepat

- Pengelolaan pengadaan lebih meningkat

- Pengetahuan lebih luas

- Diskon besar untuk pembelian banyak

3. Keuntungan desentralisai

- Komunikasi dengan end user lancar

- Tanggung jawab lebih tinggi

- Pengambilan keputusan lebih cepat

- Waktu pengadaan lebih cepat 
- Respon atas perubahan pengadaan cepat

M. Produsen vs Trader

Prinsip SCM adalah pengadaan barang dilaksanakan langsung kepada sumber pengadaan atau produsen tanpa melalui perantara yang akan menambah biaya.

N. Pemasok Internasional vs Pemasok Nasional

Sumber pengadaan luar negeri akan menghasilkan kualitas yang lebih tinggi dan harga yang kompetitif.

O. Brand Name vs Generic

Brand Name lebih disukai karena kualitas lebih terjamin, kelanjutan suplai lebih terjamin, memberikan layanan purna jual, dan konsisten memelihara reputasi produk. 
PART 10

\section{PERANAN TRANSPORTASI BARANG \& MANAJEMEN PERGUDANGAN DALAM SCM}

\section{A. Peranan Transportasi barang}

1. Peranan dan manfaat transportasi barang

Transportasi barang berpengaruh atas ketersediaan bahan baku barang jadi. Transportasi barang juga berpengaruh atas biaya produksi dan penentuan harga barang. Sistem transportasi yang efesien dan cepat akan menjamin stabilitas harga pasar.

2. Istilah Transportasi

- Mode of transport (moda transportasi)

- Means of transport (armada transportasi)

-Type of Means of transport (jenis armada transportasi)

-Multimodal Transport (multimoda transportasi)

-Unimodal transport (unimoda transportasi)

3. Moda Transportasi Jalan (road transport)

Moda transportasi jalan (road) sering disebut moda transportasi darat, dipilih berdasarkan faktor jenis dan spesifikasi alat angkut yang dibutuhkan, jarak perjalanan, tujuan perjalanan, ketersediaan alat angkut dan luas daerah. 


\section{Moda Transportasi Laut (sea transport)}

Armada transportasi laut dapat mengangkut berbagai muatan yang disesuaikan dengan jenis muatan, antara lain kapal kargo umum, kapal container, kapal muatan curah, kapal tanker, kapal RoRo (Roll-On RollOff).

5. Moda Transportasi Udara

Moda transportasi udara dapat menjangkau tempat yang tidak dapat ditempuh dengan moda transportasi jalan (road) atau laut dan mampu bergerak lebihcepat dan mempunyai lintasan yang lurus serta bebas hambatan.

6. Moda transportasi Rel (Rail Transportation)

Merupakan Moda transportasi yang digunakan pada koridor berupa kereta api yang berjalan diantara rel dan tidak fleksibel seperti moda transportasi jalan.
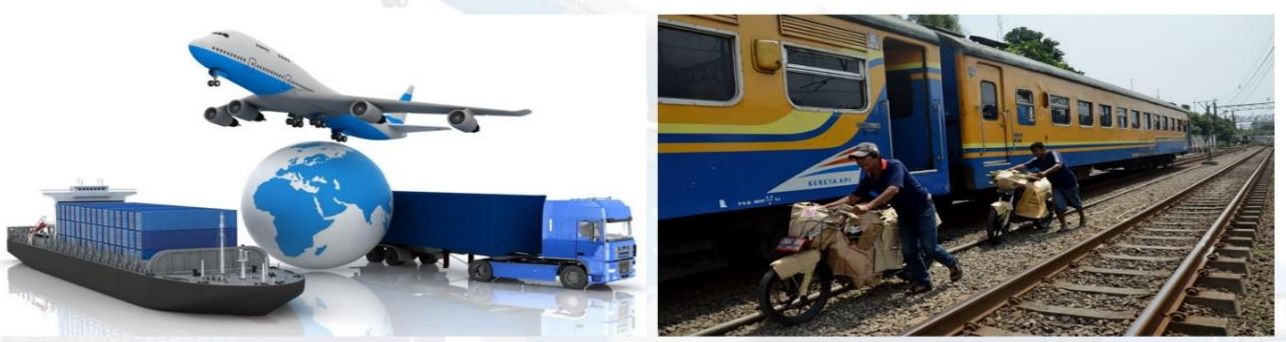

Gambar Moda Transportasi Jalan, Laut, Udara dan Rel

\section{Pemilihan Moda Transportasi}

Pemilihan penggunaan moda ditentukan oleh: 
- Jenis Pelayanan

- Keandalan

- Keselamatan dan perjalanan

- Biaya

- Jarak Tempuh

- Kecepatan

- Fleksibilitas

- Tingkat Populasi

- Penggunaan bahan bakar

8. Kargo (Muatan)

Muatan adalah seluruh jenis barang yang dapat diangkut dari suatu tempat ketempat lain dengan mempergunakan moda transportasi dan hampir seluruh jenis barang yang diperlukan oleh manusia dalam bentuk bahan baku atau produk jadi.

Label, Pada Barang dan kemasan Muatan :

- Fragile (Mudah Pecah)

- Flammable (Mudah Terbakar)

- Don't Drop (Jangan Dibanting)

- Keep Dry (tetap kering)

- Protect from heat (lindungi dari panas)

- Handle with care(tangani dengan hati-hati)

- Use no hook (jangan pakai ganco) 
- Top side (sisi sebelah atas)

- Label barang berbahaya (radioaktif)
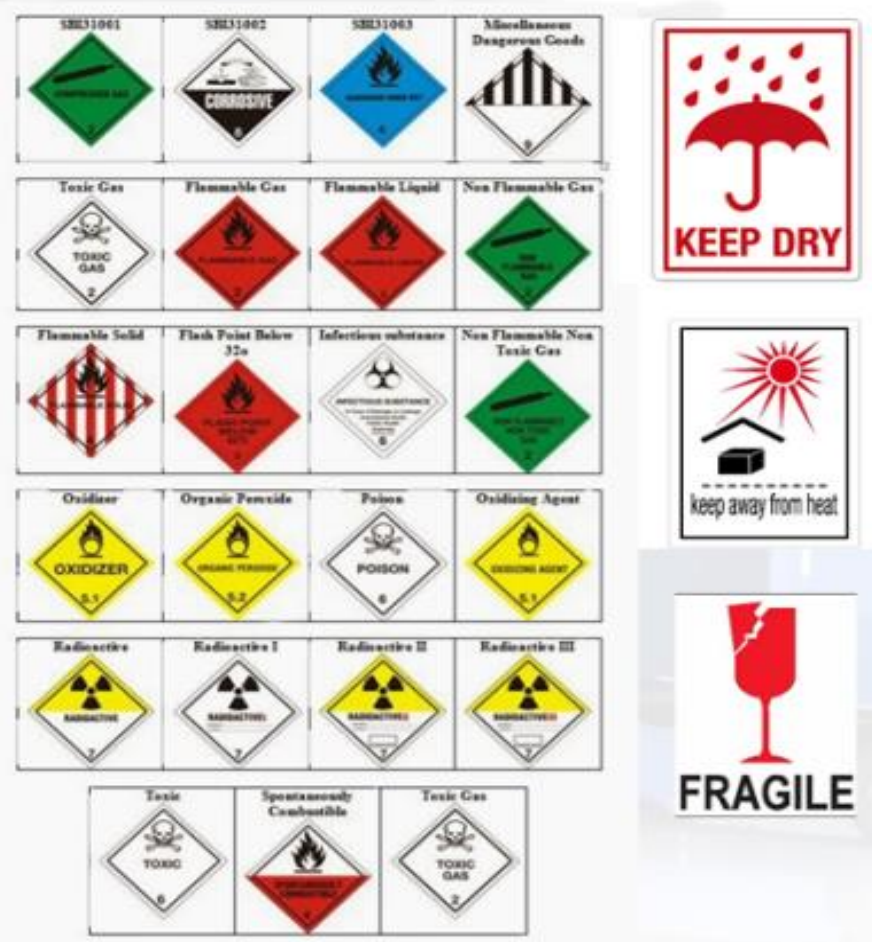

THIS END UP
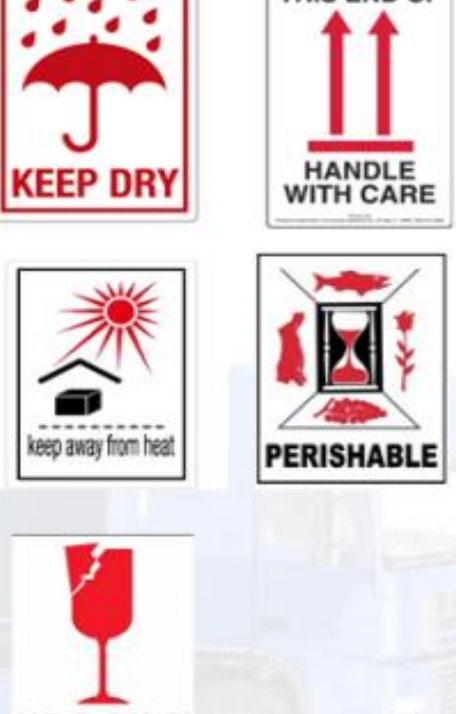

FRAGILE

\section{Kontainer (Peti Kemas)}

Kontainer adalah satu kemasan yang dirancang khusus dengan ukuran tertentu dapat dipakai berulang kali dan dipergunakan untuk menyimpan dan sekaligus mengangkut muatan yang ada di dalamnya dengan tujuan keamanan, keselamatan, kecepatan pengiriman dan efesiensi biaya. 


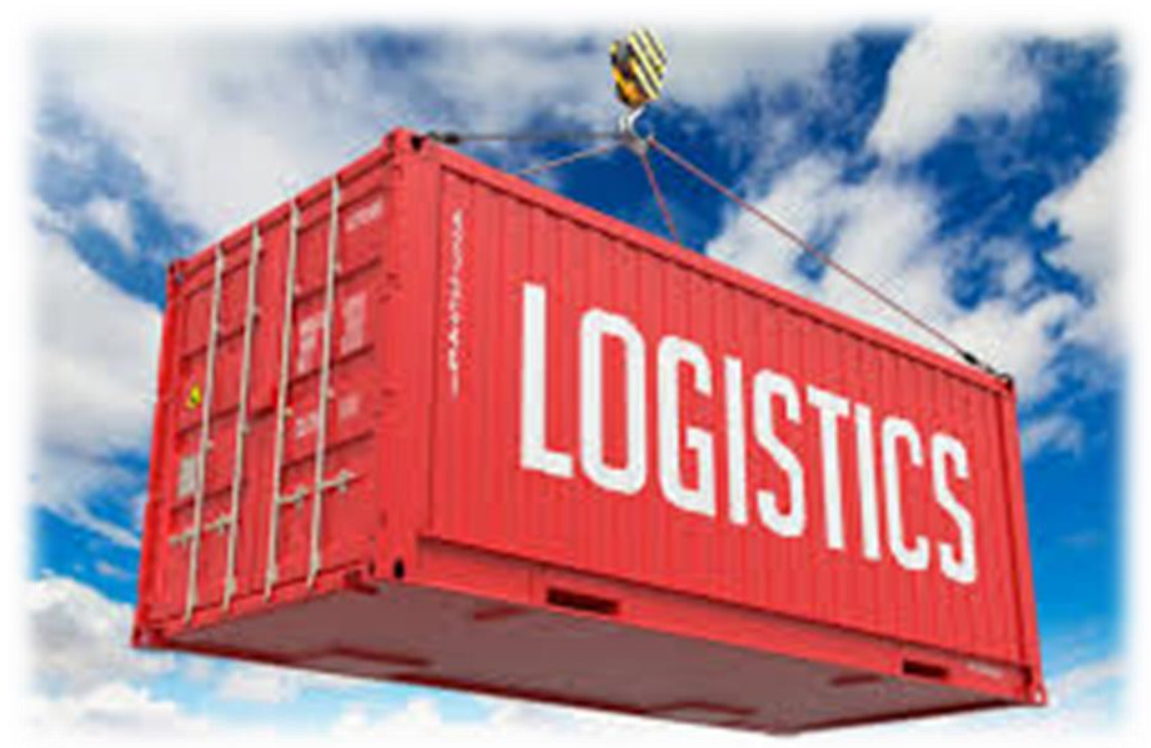

\section{Biaya Muatan}

Biaya muatan adalah jumlah biaya yang harus dibayar oleh pengirim berdasarkan berat (actual weight) atau volume (volume weight) suatu muatan dikalikan dengan tarif (rate) yang berlaku.

11. Ekspor dan Impor

Proses ekspor adalah kegiatan menjual atau mengeluarkan barang atau komoditas dari dalam negeri ke negeri lain. Impor adalah proses membeli atau memasukan barang atau komoditas dari suatu negara ke negara lain dalam hubungan perdagangan.

12. Freight Forwader

Freight Forwader atau perusahaan pengurusan jasa kepabeanan (PPJK) adalah badan usaha yang 
melaksanakan kegiatan pengurusan pengiriman, penerimaan, penyimpanan, pengepakan, pengurusan dokumen ekspor/impor, konsolidasi, perhitungan biaya angkutan, asuransi serta penyelesaian formalitas bea cukai (custom clearance).

\section{Incoterms}

Incoterms adalah singkatan dari International commercial terminologies (Terms) yang merupakan terminologi baku mengenai pengiriman barang oleh para pelaku bisnis jual-beli dalam perdagangan internasional.

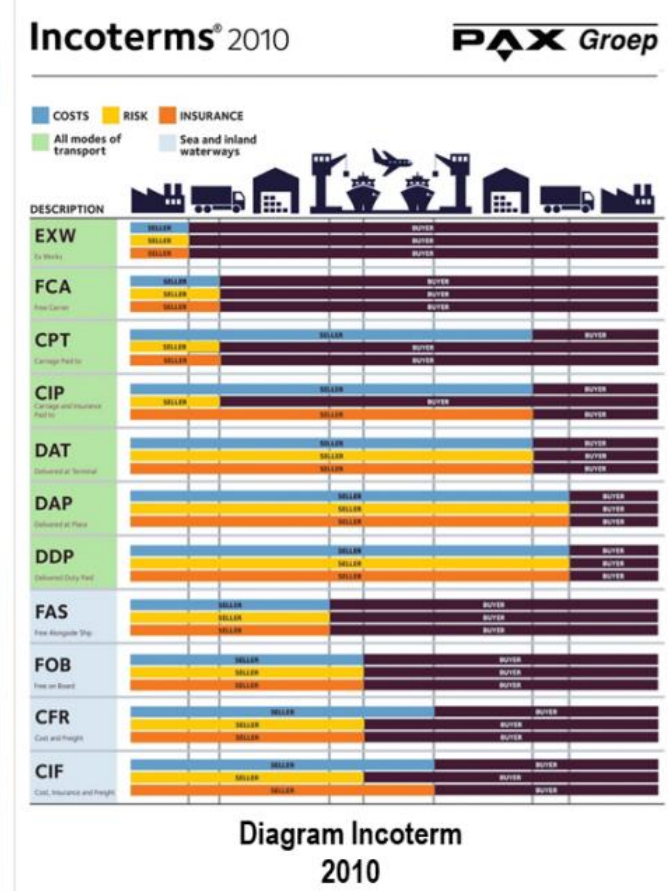


14. Hubungan Transportasi dan Distribusi

Manajemen transportasi dan manajemen distribusi merupakan pengelolaan kegiatan pergerakan produk dari suatu lokasi ke lokasi lain yang terkoordinasi dalam suatu jaringan.

15. Best Practices of transportation in SCM

- Sharing transportation facilities, memakai fasilitas transportasi secara bersama

- Outsource Transportation Function

- Optimalization Transportation Base, upaya untuk mengoptimalkan fungsi terminal

- One stop transportation service

- Cargo consolidation

- Greening transportation

- Sharing transportation information

- Real time visualization of shipment status

- Global cross sourcing services

- Increase service levels and decrase costs

\section{B. Peranan Manajemen Pergudangan dalam SCM}

Gudang adalah suatu tempat atau bangunan yang dipergunakan untuk menimbun, menyimpan barang, baik berupa bahan baku (raw material), barang setengah jadi (work in process) atau barang jadi (finished product). 
Manajemen pergudangan adalah bagian dari manajemen logistik dan SCM, merupakan pengelolaan kegiatan menerima, menyimpan, merawat, mengirim dan menatausahakan barang pada suatu tempat tertentu.

1. Jenis Gudang

- Gudang tertutup

- Gudang terbuka

- Emperan (open shed)

- Lapangan penimbunan (yard)

- Tangki

- Peti kemas

- Gudang khusus (bahan peledak)

2. Jenis Gudang Manufaktur

- Gudang operasional

- Gudang perlengkapan

- Gudang distribusi

- Gudang musiman

3. Aktivitas Pergudangan

- Penerimaan (receiving)

- Penyimpanan (storage)

- Penanganan (Handling)

- Perawatan (Up-Keep)

- Pengemasan (Packaging) 
- Pengeluaran (Dispatching)

- Pengiriman (expediting)

- Distribusi (distribution)

- Pemeriksaan dan pengawasan (control)

4. Lokasi Gudang

Penentuan lokasi gudang harus memperhitungkan nilai tambah yang memberikan keuntungan bagi perusahaan dan kepuasan bagi pelanggan.

5. Tata Letak (Layout) Gudang

Penataan tata letak gudang harus mempertimbangkan:

- Ruang gerak untuk beraktivitas

- Area bongkar dan muat barang

- Efesiensi pemakaian ruangan

- Kelancaran aliran barang

- Sistem penanganan (handling) material

- Area penyimpanan barang

- Area pengepakan

- Area inspeksi barang

- Ruang kontrol (kantor)

- Memberikan keindahan, kenyamanan, kesehatan dan keselamatan kerja. 


\section{PART 11}

\section{PERANANAN MANAJEMEN DISTRIBUSI DALAM \\ $\mathrm{SCM}$}

\section{A. Peranan Manajemen distribusi dalam SCM}

1. Pengertian Distribusi

Distribusi adalah suatu proses penyimpanan barang jadi dari produsen ke konsumen atau pemakai pada saat dibutuhkan.

2. Konsep Distribusi
a. Distribusi phisik
b. Intermoda
c. Konsolidasi
d. Cross docking
e. Unitisasi
f. kontainerisasi

3. Sistem Distribusi

a. Sistem distribusi dorong (push system)

Sistem distribusi dorong berdasarkan peramalan kebutuhan, dimana inisiatif dan penggerak aktivitas distribusi berasal dari produsen.

b. Sistem distribusi tarik (pull system) 
Sistem distriusi tarik berdasarkan permintaan pelanggan dan penggerak aktivitas produksi dan distribusi berasal dari konsumen.

4. Fungsi manajemen distribusi

a. Melakukan segmentasi pasar

b. Menentukan moda transportasi yang tepat

c. Konsolidasi sistem informasi dan pelaksanaan pengiriman

d. Menjadwalkan dan rute pengiriman

e. Mengelola persediaan barang jadi

f. Menangani pengembalian barang (return)

g. Menentukan target tingkat pelayanan (service level)

3. Sistem Distribusi

a. Sistem distribusi dorong (push system)

Sistem distribusi dorong berdasarkan peramalan kebutuhan, dimana inisiatif dan penggerak aktivitas distribusi berasal dari produsen.

b. Sistem distribusi tarik (pull system)

Sistem distriusi tarik berdasarkan permintaan pelanggan dan penggerak aktivitas produksi dan distribusi berasal dari konsumen.

4. Fungsi manajemen distribusi

a. Melakukan segmentasi pasar 
b. Menentukan moda transportasi yang tepat

c. Konsolidasi sistem informasi dan pelaksanaan pengiriman

d. Menjadwalkan dan rute pengiriman

e. Mengelola persediaan barang jadi

f. Menangani pengembalian barang (return)

g. Menentukan target tingkat pelayanan (service level)

5. Strategi Distribusi

a. Direct shipping (DS)

Pelayanan point to point

- Tidak ada fasilitas antara, seperti gudang dan pusat distribusi (distribution center).

- DSD (direct store delivery), pabrik pembuat mengirimkan barang langsung ke retail.

b. Strategi warehousing (SW)

- Produk disimpan di gudang/distribution center sebelum dikirim ke pelanggan.

- Pengguna gudang adalah penjual produk khusus seperti buku dan pakaian.

c. Strategi Cross-docking

Memindahkan produk secara langsung antar moda transportasi pada tempat tertentu yang disediakan dan 
disepakati, tanpa menggunakan fasilitas gudang atau penyimpanan sementara.

6. Saluran Distribusi

Saluran distribusi adalah serangkaian perusahaan yang saling terkait dan terlibat dalam proses penyampaian atau penyaluran barang dari produsen ke konsumen.

7. Model Saluran Distribusi

a. Produsen - Konsumen

b. Produsen - Retailer (Pengecer) - Konsumen

c. Produsen - Distributor - Retailer - Konsumen

8. Jenis Saluran Distribusi

a. Distribusi intensif

Produsen memilih sebanyak mungkin retailer (outlet) dalam suatu daerah pemasaran tertentu.

b. Distribusi selektif

Produsen memilih beberapa distributor untuk menyalurkan produknya.

c. Distribusi ekseklusif

Produsen hanya menunjuk satu distributor untuk mendistribusikan produk tertentu.

9. Faktor Struktur Saluran Distribusi

Struktuf Saluran Distribusi dipengaruhi oleh faktor:

a. Response time 
b. Product variety

c. Product availability

d. Customer experience

e. Time to market

10. Model Distribusi Produk

a. Pengiriman langsung (Drop Shipping)

b. Pengiriman produk melalui transit

c. Distribusi produk melalui distributor

d. Distribusi melalui desentralisasi

e. Pengambilan langsung oleh konsumen

11. Metoda Distribusi

Metode distribusi terdiri dari metoda stepping stone dan metoda VAM (vogel's approximation method), dipergunakan untuk menghitung dan menentukan alokasi dan biaya distribusi yang paling optimal melalui stimulasi dan metrik berdasarkan data kapasitas produksi, kebutuhan pelanggan, jarak tempuh dan biaya pengangkutan.

12. Konsolidasi Muatan (cargo consolidation)

Konsolidasi muatan adalah kegiatan pengumpulan muatan dari beberapa sumber di pelabuhan muat, kemudian disatukan menurut tujuan yang sama.

13. Faktor Pendorong Penggunaan Distributor 
a. Produksi ingin lebih berkonsentrasi pada proses produksi

b. Produsen tidak mau terlibat dalam praktik bisnis penjualan

c. Produsen kecil tidak mau berinvestasi di jalur distribusi

d. Distributor pasti lebih ahli dan efisien di bidang distribusi

e. Distributor mempunyai jaringan pasar yang lebih luas

f. Retailer lebih cenderung mau berbisnis dengan distributor daripada produsen

14. Keuntungan Menggunakan Distributor

a. Produsen lebih efesien dalam kegiatan distribusi untuk mencapai konsumen

b. Distributor lebih berpengalaman dalam kegiatan distribusi

c. Distributoir menyediakan peralatan dan sarana pendukung kegiatan distribusi

d. Distributor menyediakan fasilitas penyimpanan produk bila sewaktu-waktu dibutuhkan oleh konsumen.

e. Distributor membantu untuk mendapatkan konsumen dan kegiatan promosi serta informasi.

15. Meningkatkan Produktivitas Distribusi 
a. Membangun tanggung jawab individual dalam setiap tingkat organisasi

b. Membangun metoda dan prosedur standar kerja

c. Fokus kepada semua lini aktivitas distribusi

d. Pelatihan kompetensi operator dan pengawas

e. Fleksibel dan melakukan perubahan menuju perbaikan

f. Memanfaatkan sistem informasi

16. Indikator Keberhasilahn Distribusi

Ukuran keberhasilan distribusi berdasarkan:

a. Fleksibilitas,kemampuan untuk memenuhi perubahan kebutuhan pelanggan, menyangkut jumalh (kuantitas), kualitas (spesifikasi) dan waktu penyerahan (delivery time)

b. Ketepatan waktu untuk memenuhi permintaan barang dari pelanggan (on time)

c. Ketersediaan produk saat dibutuhkan pelanggan

d. Kecepatan dan akurasi informasi

e. Tanggap terhadap perbaikan, kerusakan dan klaim atas barang yang rusak. 


\section{PART 12}

\section{PERANAN MANAJEMEN PELANGGAN DAN INVENTORI}

\section{A. Peranan manajemen pelanggan dalam SCM}

Tuntutan konsumen bukan hanya sebatas pada produk dan jasa saja, tetapi mencakup nilai (costumer value) yang diterima konsumen dari hubungan dengan produsen.

1. Pengelolaan pelanggan (customer management)

Kepuasan pelanggan bukan saja saat menerima barang. Pelayanan pelanggan merupakan nilai tambah untuk mendapatkan kepercayaan dan kesetiaan pelanggan.

2. Tanggung jawab pelayanan pelanggan
a. Informasi kepada pelanggan
b. Tanggap terhadap masalah
c. Dukungan teknis
d. Layanan perawatan dan perbaikan

3. Elemen pelayanan pelanggan
a. Elemen Pra-transaksi (pre-transaction element)
b. Elemen Transaksi
c. Elemen Post-transaksi 
4. Customer relationship management (CRM)

CRM merupakan strategi bisnis suatu perusahaan yang memungkinkan perusahaan tersebut secara efektif bisa mengelola hubungan dengan pelanggan.

5. Value-Added Service

Perusahaan tidak dapat bersaing dengan hanya berdasarkan pada harga produk saja, tetapi juga faktor lain yang dapat memberi nilai tambah bagi konsumen.

6. Kemampuan SCM vs Kebutuhan Pelanggan

\begin{tabular}{|l|l|}
\hline \multicolumn{1}{|c|}{ Kemampuan SCM } & \multicolumn{1}{c|}{ Kebutuhan Pelanggan } \\
\hline Beroperasi secara efisien & Produk Murah \\
\hline Menciptakan kualitas & Produk Berkualitas \\
\hline Layanan cepat & Tepat Waktu \\
\hline Fleksibel & Perubahan Kebutuhan \\
\hline inovatif & Produk Variatif \\
\hline
\end{tabular}

7. Indikator Kinerja Pelayanan Pelanggan (Customer

Service Performance Indicators)
a. Ketersediaan produk
b. Performa operasional
c. Kehandalan
d. Kualitas
e. Transportasi dan distribusi 


\section{B. Peranan Manajemen Inventori dalam SCM}

1. Pengertian Inventori (persediaan)

Persediaan (inventori) adalah sejumlah material yang disimpan dan dirawat menurut aturan tertentu dalam tempat persediaan agar selalu dalam keadaan siap pakai dan ditatusahakan dalam buku perusahaan.

2. Jenis persediaan
a. Bahan baku (raw material)
b. Bahan setengah jadi (semi finished product)
c. Barang jadi (finished product)
d. Material MRO (maintenance, repair, operation)
e. Perkakas (tools)
f. Barang dagangan (commodities)

3. Kategori Persediaan

a. Kategori A

Kelompok A adalah item persediaan yang bernilai besar namun merupakan bagian kecil dari keseluruhan item persediaan.

b. Kategori B

Kelompok B adalah item persediaan yang memiliki nilai rendah namun merupakan bagian terbesar dari seluruh persediaan.

c. Kategori C 
Kelompok $\mathrm{C}$ adalah item persediaan yang tidak termasuk dalam kategori A maupun B.

\section{\begin{tabular}{l|l|l} 
Kategori & Nillai lnventori $\%$ & Jumlah Inventori \% \\
\hline
\end{tabular}}

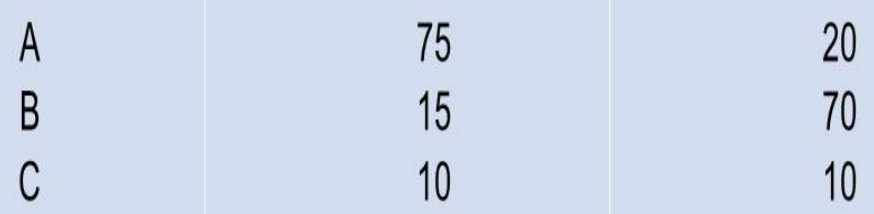

4. Manfaat persediaan

a. Jaminan atas permintaan yang tak terduga

b. Menghilangkan risiko terlamar dan kerusakan

c. Jaminan terputusnya pasokan

d. Memenuhi permintaan musiman

e. Menghilangkan risiko transportasi

f. Mempertahankan stabilitas produksi dan operasi

g. Penggunaan mesin produksi optimal

h. Jaminan kepastian ketersediaan barang jadi.

i. Mengantisipsi kenaikan harga.

5. Biaya persediaan
a. Ordering cost
b. Biaya kapital, modal yang ditanamkan
c. Inventory carrying cost
d. Biaya shortage, biaya pemesanan ulang (back order) 
6. Inventory control

Tujuan inventory control

a. Menjaga supaya perusahaan tidak kehabisan persediaan

b. Menjaga supaya tingkat persediaan tidak kekurangan dan tidak kelebihan (tinggi)

c. Menghindari pembelian berkali-kali (biaya pemesanan tinggi)

Penentuan jumlah pesanan

- EOQ (Economic Order Quantity)

$\mathrm{EOQ}=\sqrt{\frac{2 R F}{P C}}$

EOQ = kuantitas pemesanan

$\mathrm{R}=$ kebutuhan persediaan 1 tahun

$\mathrm{F}$ = biaya setiap kali pemesanan

$\mathrm{P}=$ harga beli per unit

$\mathrm{C}$ = Biaya Penyimpanan (\%)

- Min-Max

Min = pemakaian sebulan $\mathrm{x}$ waktu pemesanan + safety stock

Max = pemakaian sebulan $\mathrm{x} 2$ (waktu pemesanan)

7. Stockout (kehabisan Stock)

a. Stockout disebabkan oleh: 
- Jumlah permintaan lebih besar dibandingkan dengan jumlah persediaan bahan baku maupun barang jadi tersedia di gudang.

- Peramalan kebutuhan barang tidak akurat

- Penentuan jumlah pesanan bahan baku yang tidak tepat

b. Kerugian akibat stockout

- Kehilangan penjualan, disebabkan tidak dapat memenuhi kebutuhan pelanggan.

- Kehilangan pelanggan, karena kehabisan persediaan maka pelanggan akan beralih ke produk lain. 


\section{PART 13}

\section{PERANAN MANAJEMEN MATERIAL \& ASET DALAM SCM}

\section{A. Peranan Manajemen Material dalam SCM}

1. Jenis Material

Material adalah bahan yang tidak dapat disentuh, digunakan, disusun dan dibuat seperti kayu, besi, plastik, kaca, karet, aluminium, semen, batu bata dan kertas. Material terdiri atas dua yaitu material berwujud dan material tidak berwujud.

2. Struktur Material

a. Metal (metalic materials)

- Ferrous

- Cast Iron

- Malleable Iron (besi tuang)

- Carbon Steel (SC)

- Saintless Steel (SS)

- Non ferrous

- Carbon, ceramic, glass, rubber, wood

- Aluminium (Al) dihasilkan dari bauksit

- Tembaga/cooper $(\mathrm{Cu})$ 
- Bronze, campuran tembaga dan timah putih (Tin)

3. Barang Dagang

Barang dagang adalah benda dalam berbagai berntuk dan uraian, yang meliputi bahan baku, barang setengah jadi, barang jadi dan peralatan.

4. Spesifikasi material

Spesifikasi material adalah uraian rinci dari karakteristik suatu material yang meliputi nama, jenis, ukuran, bahan, fungsi/kegunaan, rancang, bangun dan kode dari pabrikan (tipe, model, serial number, part number dan drawing number), serta standar material umum yang diberlakukan atau dirujuk (API, ASTM, BS, JIS, SNI).

5. Penulisan spesifikasi material

Line Pipe, 6 in, Welded, Carbon Steel $(0.23 \%$ max),API 5L, Wall-thickness $5.49 \mathrm{~mm}$, Schedule 40, Double Random Length, Bevelled End 30 Degree, Loose, Coated.

Line Pipe : Pipa baja untuk aliran fluida

6 in : Diameter 6 Inch

Welded : Sambungan Las

CS $(0.23 \%$ max $)$ : Carbon steel dengan kadar Carbon maksimum $0.23 \%$ 
API 5L

: American Petroleum Institute,

standard Line Pipe

Wall-thickness $5.49 \mathrm{~mm}$ : Tebal pipe $5.49 \mathrm{~mm}$

Schedule 40

: 150 PSI (paund Square Inch)

Double Random Length : Panjang 11-14 mtr

Bevelled End 30 Degree : ujung pipe di-bevel dengan kemiringan 30 derajad

Loose

: Diangkut secara batangan

Coated

: Dilapisi Anti Karat

6. Standarisasi dan kode material

Standarisasi adalah spesifikasi teknis yang baku dan disusun dengan mempertimbangkan faktor perkembangan IPTEK dan HSE (Health, safety, Environment).

B. Peranan Manajemen Aset dalam SCM

\section{Peranan Aset dalam SCM}

Kesiapan dan kehandalan aset penunjang kegiatan SCM, seperti pabrik, gudang, peralatan handling, sarana transportasi dan gedung kantor (pusat kontrol) akan memperlancar dan mengsukseskan tugas kegiatan aliran barang mulai dari pemasok sampai konsumen.

2. Pengertian set

Aset merupakan sebuah kekayaan yang berbentuk barang atau benda yang terdiri dari benda bergerak baik 
yang berwujud maupun tidak berwujud yang tercakup dalam aktiva/kekawaan perusahaan.

3. Pengertian Manajemen Aset

Manajemen aset merupakan proses pengelolaan aset (kekayaan) baik berwujud dan tidak berwujud yang memiliki nilai ekonomis, nilai komersial dan nilai tukar.

4. Jenis Aset

a. Aset Berdasarkan Bentuk :

- Aset berwujud (tangible)

- Aset tidak berwujud (tangible)

b. Aset Berdasarkan Kategori

- Aset Lancar (current Asset)

- Aset Tetap (Fixed Asset)

5. Tujuan Manajemen Aset

a. Meminimalkan biaya selama umur aset

b. Menghasilkan laba yang maksimum

c. Memanfaatkan aset secara optimal

d. Mengembangkan fungsi aset untuk pencapaian target perusahaan.

e. Mencapai tertib administrasi.

6. Umur Manfaat Aset (Asset Cycle Time)

Umur manfaat aset adalah waktu dimana suatu aset diharapkan dapat memberikan manfaat/pelayanan 
bagi perusahaan. Berdasarkan pada sifat aset, umur manfaat dapat dinyatakan dalam istilah waktu (tahun) ataupun output (unit produksi atau pelayanan).

7. Azas Pengelolaan Aset
a. Azas fungsional
b. Azas kepastian hukum
c. Azas transparansi
d. Azas efesiensi
e. Azas akuntabilitas
f. Azas kepastian nilai

8. Perencanaan Aset

Perencanaan aset merupakan hal fundamental bagi perusahaan dan bisnis yang merupakan langkah pertama dan bisnis yang merupakan langkah pertama dalam siklus hidup aset.

9. Pengadaan Aset

Pengadaan aset baru dan penggantian aset yang kinerjanya telah menurun, memerlukan perencanaan, karena menyangkut biaya investasi.

10. Tahapan Kerja Aset

a. Inventarisasi Aset

b. Legal audit

b. Penilaian aset 
c. Optimalisasi aset

d. Pengawasan dan pengendalian aset

11. Evaluasi Kinerja Aset

a. Evaluasi kondisi fisik

b. Evaluasi pemanfaatan

b. Evaluasi Fungsionalitas

c. Evaluasi Kinerja Keuangan

12. Pemeliaharaan Aset

Tujuan pemeliharaan aset untuk mempertahankan dan meningkatkan performa atau kinerja aset.

13. Depresiasi (penyusutan)

Penyusutan adalah penyesuaian nilai sehubungan dengan penurunan kapasitas dan mand]faat dari suatu aset, sesuai dengan sifat dan karakteristik .

14. Penghapusan Aset

Perimbangan penghapusan aset

a. Kurang bermanfaat dan berkinerja jelek

b. Mengakibatkan pemborosan

c. Berdampak pada pencemaran lingkungan

d. Meminimalkan aset yang berlebih dan usang 
PART 14

\section{PERANAN MANAJEMEN PERAMALAN KEBUTUHAN, INFORMASI, KUALITAS DAN LINGKUNGAN DALAM SCM}

\section{A. Peranan Manajemen Peramalan Kebutuhan Dalam SCM}

Peramalan kebutuhan (demand forecasting) adalah prosesuntuk memeperkirakan berapa kebutuhan dimasa datang berupa kebutuhan dalam ukuran kuantitas, kualitas, waktu dan lokasi yang dibutuhkan dalam rangka memenuhi permintaan barang atau jasa.

Teknik peramalan kebutuhan meliputi:

1. Teknik peramalan kualitatif

Teknik peramalan yang menggabungkan faktor intuisi, emosi, pengalaman, dan sistem nilai sebagai pengambil keputusan peramalan.

2. Teknik peramalan kuantitatif

Peramalan time-series

Teknik peramalan yang menggunakan data masa lalu untuk melakukan peramalan. Model time-series membuat prediksi dengan asumsi bahwa masa depan 
merupakan fungsi masa lau dengan melihat apa yang terjadi selama kurun waktu tertentu.

\section{B. Peranan Manajemen Informasi Dalam SCM}

1. Peranan teknologi informasi dalam SCM

Meningkatkan efesiensi kegiatan supply chain dengan menyediakan informasi terkini tentang availibilitas produk, tingkat persediaan dan status pengiriman.

2. Perspektif teknologi informasi dalam SCM

a. Perspektif teknis

Teknologi informasi menjadi sarana untuk mengubah fakta dan peristiwa bisnis terkini kedalam format data kuantitatif.

b. Perspektif manajerial

Implementasi efektif sebuah teknologi informasi dalam pelaksanaan SCM akan mengurangi resiko ketidakpastian dan biaya serta mengoptimalkan proses aliran barang.

3. Keterlibatan teknologi informasi dalam SCM

a. Electronic data intercharge (EDI)

b. Enterprise resource planning (ERP)

c. Virtual enterprise (VE)

4. Electronic SCM (e-SCM) 
e-SCM merupakan suatu alternatif baru menuju pembangunan pelaksanaan pengembangan pelaksanaan aktivitas supply chain yang lebih cepat, efektif dan efisien secara terintegrasi dan terkoordinasi.

\section{Peranan Manajemen Kualitas dalam SCM}

1. Pengendalian Mutu (Quality Control)

Quality control adalah prosedur untuk memastikan bahwa barang yang diproduksi atau jasa yang dihasilkan sesuai dengan standar dan kriteria kualitas dan memenuhi persyaratan.

2. Tolal Quality Management (TQM)

TQM merupakan implementasi pengelolaan sistem pengendalian mutu yang dilaksanakan berdasarkan prinsip :

a. Melaksanakan kegiatan pengendalian mutu yang berfokus kepada pemenuhan kebutuhan dan kepuasan pelanggan

b. Melakukan perbaikan terus menerus (continuous improvement).

c. Melibatkan seluruh kekuatan sumber daya dalam perusahaan.

3. Quality Assurance (QA) 
Kegiatan quality assurance adalah meneliti dan memahami kebutuhan konsumen dan menentukan standar dan prosedur proses pembuatan produk.

\section{Peranan Manajemen Lingkungan dalam SCM}

1. Pendorong Implementasi GrSCM

Lingkungan hijau tidak lagi menjadi pilihan melainkan suatu keharusan bagi semua perusahaan. Perusahaan menyadari bahwa green SCM merupakan solusi "win-win" antara bisnis dan lingkungan.

2. Produk dan Lingkungan

Konvensi internasional melarang beberapa jenis bahan kimia yang berbahaya bagi lingkungan. banyak negara telah menghilangkan bahan kimia berbahaya dari proses produksi dan mengawasi secara ketat peredaran barang berbahaya yang merusak lingkungan dan kesehatan manusia.

3. Transportasi dan Lingkungan

Memperhatikan tatacara pengangkutan jenis barang yang membutuhkan perlakuan khusus. Bahan pengekapan terdiri dari material yang dapat didaur ulang dan menimbulkan sampah. 


\section{DAFTAR PUSTAKA}

Agus, A. (2015). Supply Chain Management: The Influence of SCM on

Production Performance and Product Quality. Journal of Economics,

Business and Management, 1046-1053.

Anatan, Lina., dan Lela Ellitan., "Supply Chain Managemen Teori dan Aplikasi".

Alfabeta. Bandung. 2014

Bhatnagar,Ashish. 2009. "Text Book of Supply Chain

Management”.

India: Word-Press

Chopra, Sunil., dan Meindl. Peter., "Supply Chain

Management: Strategy,

Planning, and Operation". Pretince-Hall. New Jersey. 2007

Djiwandono, P. I. (2015). Meneliti Itu Tidak Sulit.

Jogjakarta: Deepublisher.

Heider, J., \& Render, B. (2015). Manajemen Operasi :

Manajemen

Keberlangsungan dan Rantai Pasokan. Jakarta :

Penerbit Salemba Empat.

Heizer, Jay., and Barry Render., "Operation Management".

Pretice-Hall, Inc.

Upper Saddle River. New Jersey. 2004. 
Indrajit, R. E., \& Djokopranoto, R. (2002). Konsep

Manajemen Supply Chain :

Cara Baru Memandang Mata Rantai Penyediaan

Barang. PT. Gramedia Widiasarana Indonesia.

Jakarta.

Levi et al. 2000. "Designing and Managing the Supply

Chain”. 2000.

USA: McGraw-Hill

Marimin, Nurul Maghfiroh. (2010). Aplikasi Teknik

Pengambilan Keputusan

dalam Manajemen Rantai Pasok. Bogor: IPB Press.

Maulani, F., Suraji, A., \& Istijono, B. (2014). Analisis Struktur Rantai Pasok

Konstruksi pada Pekerjaan Jembatan. Jurnal Rekayasa Sipil, 1-8.

Paul, J. (2014). Panduan Penerapan Transformasi Rantai Suppli dengan Model

SCOR. Jakarta : PT Pustaka Binaman Pressindo.

Pujawan, I N., \& Er, M. 2017. Supply Chain Management Edisi 3. Yogyakarta :

Penerbit Andi.

Rahmawati, R., Agung, A. A., \& Sukmawati, F. (2015).

Aplikasi Perhitungan

Persediaan Bahan Baku dengan metode EOQ

Berdasarkan Varian Produk.Jurnal Eproc, 1-8. 
Siagian, Yolanda M., "Aplikasi Supply Chain Management dalam Dunia Bisnis".

Grasindo. Jakarta. 2005.

Siahaya, Willem. (2013). Sukses Supply Chain Management Akses Demand Chain

Management. Jakarta : Penerbit In Media.

Simon, A. T., Di Serio, L. C., \& Pires, S. R. (2015).

Evaluating Supply Chain

Management: A Methodology Based on a

Theoretical Model. RAC Rio de Janeiro, 27-44.

Steeneken, F., \& Ackley, D. (2012, Januari). A Complete Model of the

Supermarket Business. BPTrends.

Stevenson, W. J. (2012). Operations Management 11th Edition. New York:

McGraw Hill.

Supply Chain Council., "Supply Chain Operation Reverence Model.Overview of

SCOR: Supply Chain Council". 2008.

Trienekens, Jacques H. dan Hans Henrik Hvolby. 2000.

"Performance

Measurement and Improvement in Supply Chain".

Dublin: CINet Conference

Widyarto, A. (2012). Peran Supply Chain Management dalam Sistem Produksi dan Operasi Perusahaan. Benefit Jurnal Manajemen dan Bisnis, Vol. 16, No. 2. (hlm. 91-98). 


\section{BIODATA PENULIS}

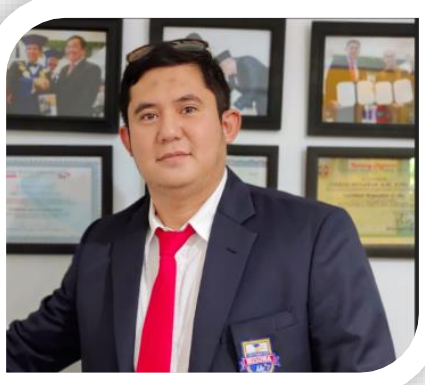

Dr. Lukman S., S.Si., S.Psi., SE., MM.

Latar Belakang Pendidikan Formal :

2017 : Doktor Ilmu Ekonomi Universitas Hasanuddin

2012 : Magister Manajemen Universitas Indonesia Timur

1999 : Sarjana Fisika Universitas Hasanuddin

2014 : Sarjana Psikologi Universitas Indonesia Timur

2015 : Sarjana Ekonomi STIE Wira Bhakti

Latar Belakang Pendidikan Formal :

Melalui Pelatihan dengan Gelar :

2015 : CH., CH.t From Indonesian Board Himnotherapy (IBH)

2015 : CH.p.,CTCM.,CMP From Sinergi Motiva Indonesia

2015 : CTNNLP.,CMNNLP From NLP Society

2021 : CSEM., CSRP., CFHA., CHA., HCMP., CHCMP., CPHCEP., AHCM., HCMP., APHA., CPHA., CPSP., CODP., CSOPA., CSSIT., CETP 
From IEEEL INSTITUTE.

\section{Saat ini Sebagia Dosen Tetap Program Studi Manajemen Fakultas Ekonomi dan Bisnis di} Universitas Bosowa, juga menjabat sebagai Direktur Bosowa Education (BEI) di Yayasan Aksa Mahmud, serta menjabat sebagai Ketua Career Development Center (CDC) Universitas Bosowa, Wakil Dekan III Bidang Kemahasiswaan dan Alumni Fakultas Ekonomi dan Bisnis Universitas Bosowa (2018 - 2019). Direktur Lembaga Self \& Organization Learning Indonesian Development (SOLID) Buku yang pernah diterbitkan : Kecerdasan Emosional di Rumah Sakit, Manajemen dengan Kecerdasan Emosional di Rumah Sakit, The Science of Emotional Intelligent Editor By Simon George Taukeni, Knowledge Sharing Di Rumah Sakit, Report Tracer Study 2016 - 2021 Universitas Bosowa, User Survey Universitas Bosowa. Jurnal : The Effect of Emotional Inttelligence on The Team Perforamnce of Hospital Officers I South Sulawesi and Central Sulawesi Province, Indonesia, Publisher Emerald Group Publishing Ltd. ISBN 0828866 (Q3). 